WATER-LEVEL DATA FOR THE

ALBUQUERQUE BASIN, NEW MEXICO,

PERIOD OF RECORD THROUGH SEPTEMBER 30, 1995

By Dale R. Rankin

U.S. GEOLOGICAL SURVEY

Open-File Report 96-664A

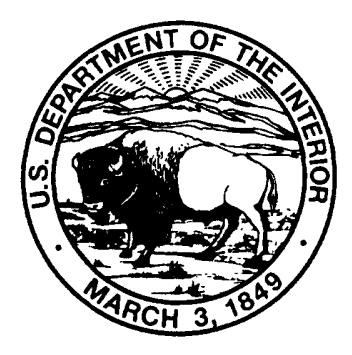

Prepared in cooperation with the CITY OF ALBUQUERQUE

Albuquerque, New Mexico

1996 


\section{U.S. DEPARTMENT OF THE INTERIOR \\ BRUCE BABBITT, Secretary}

\section{U.S. GEOLOGICAL SURVEY}

Gordon P. Eaton, Director

The use of firm, trade, and brand names in this report is for identification purposes only and does not constitute endorsement by the U.S. Geological Survey

For additional information write to:

District Chief

U.S. Geological Survey

Water Resources Division

4501 Indian School Road NE, Suite 200

Albuquerque, NM 87110-3929
Copies of this report can be purchased from:

U.S. Geological Survey

Branch of Information Services

Box 25286

Denver, CO 80225-0286 


\section{CONTENTS}

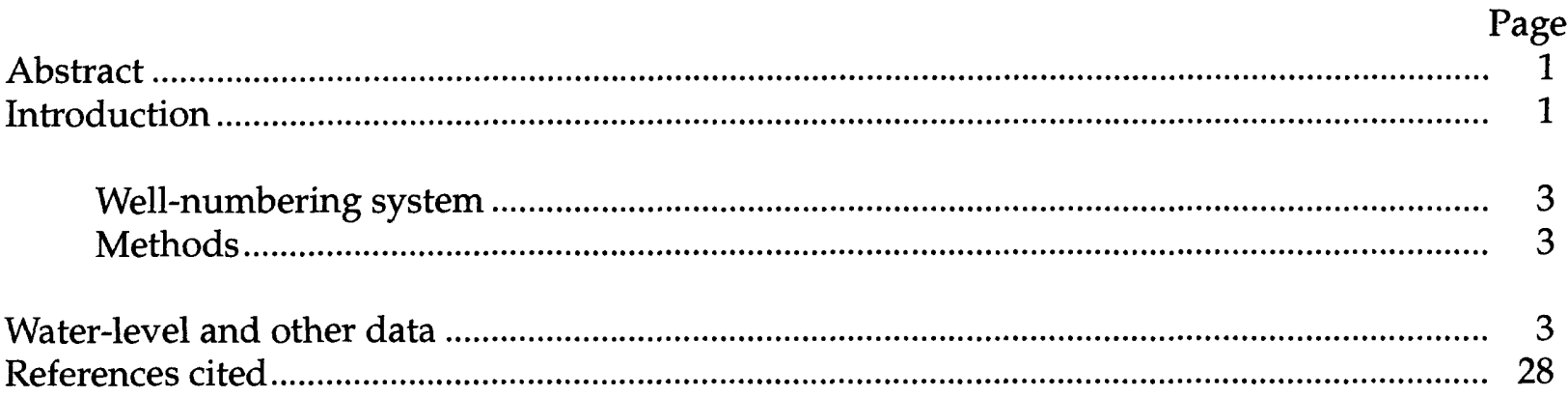

\section{FIGURES}

1. Map showing location of study area................................................................................. 2

2. Diagram showing system of numbering wells in New Mexico........................................... 4

3. Hydrographs showing water-level data for selected wells and piezometers in the Albuquerque Basin:

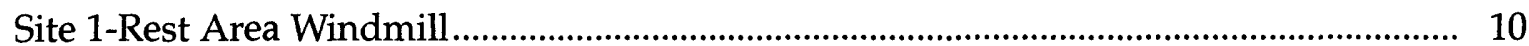

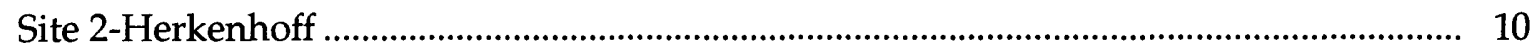

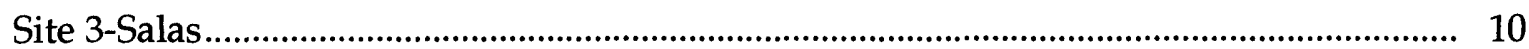

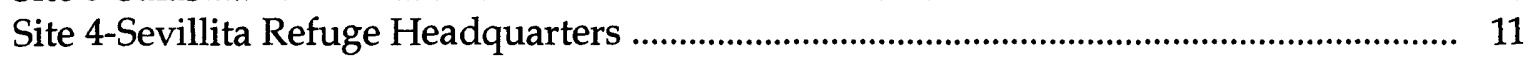

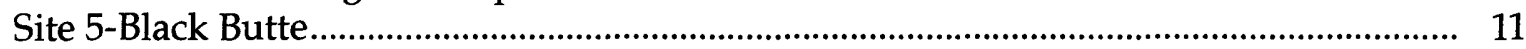

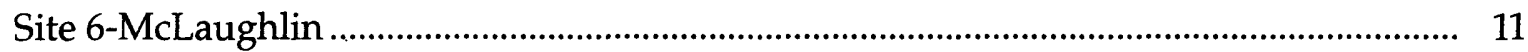

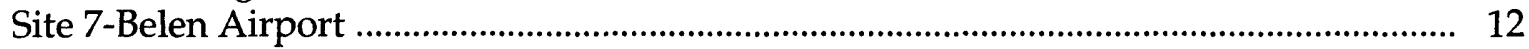

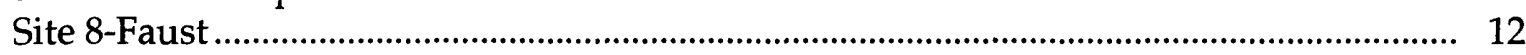

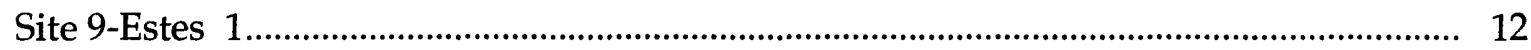

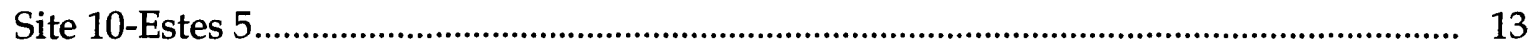

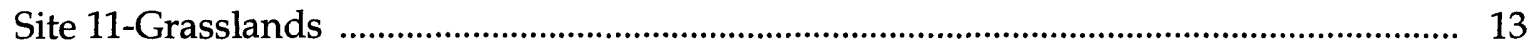

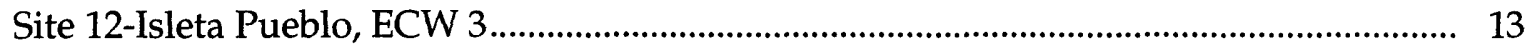

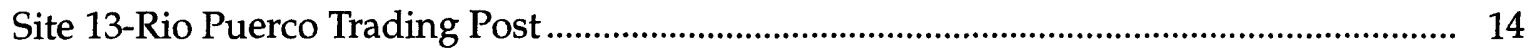

Sites 14, 15, 16-Rio Bravo Piezometer Nest 1 ............................................................. 14

Sites 17, 18, 19-Rio Bravo Piezometer Nest 2 ......................................................... 14

Sites 20, 21, 22-Rio Bravo Piezometer Nest 3 .................................................................. 15

Sites 23, 24, 25-Rio Bravo Piezometer Nest 4 ............................................................... 15

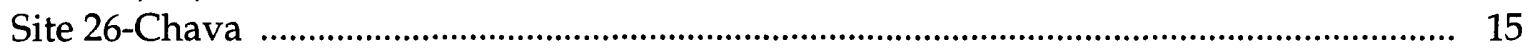

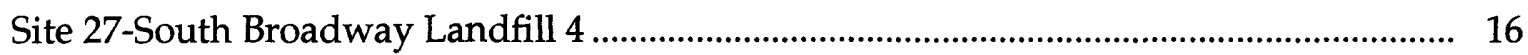

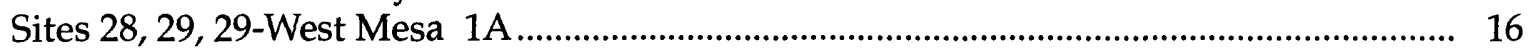

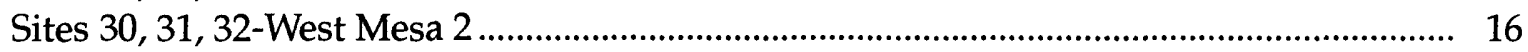

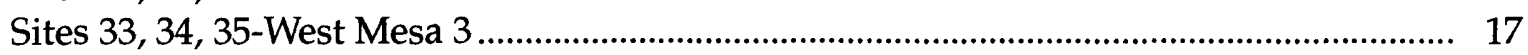

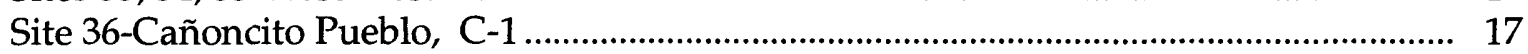

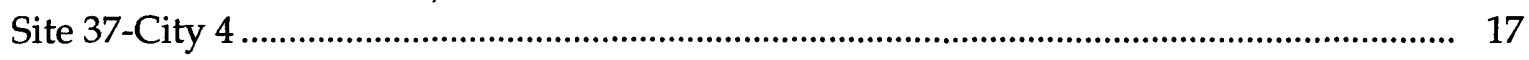




\section{FIGURES--Concluded}

3. Hydrographs showing water-level data for selected wells and piezometers in the

Albuquerque Basin--Concluded:

Site 38-BIA

Site 39-City 1

Site 40-Granite Hill

Site 41-Four Hills

Site 42-Eubank

Site 43-Home Oil

Site 44-Sink Hole

Site,45-KAFB 5

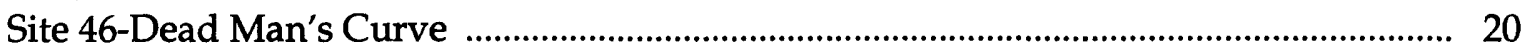

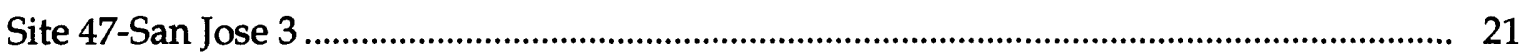

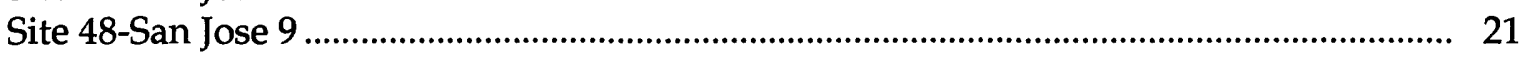

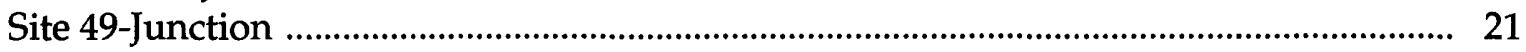

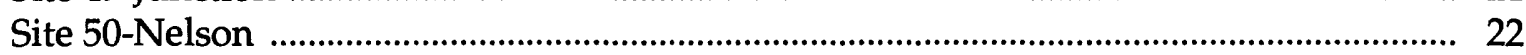

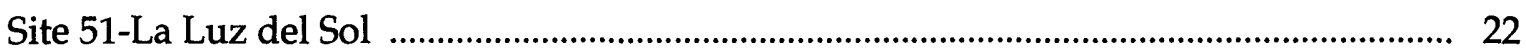

Sites 52, 53, 54-Montaño Piezometer Nest 1....................................................................... 22

Sites 55, 56, 57-Montaño Piezometer Nest 2 ............................................................... 23

Sites 58, 59, 60-Montaño Piezometer Nest 3.................................................................... 23

Sites 61, 62, 63-Montaño Piezometer Nest 4.................................................................... 23

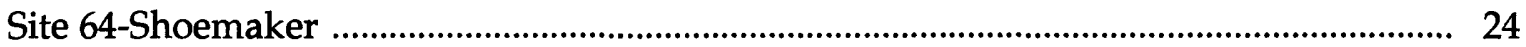

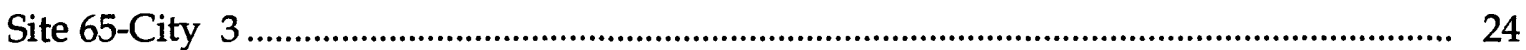

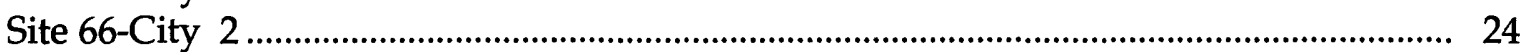

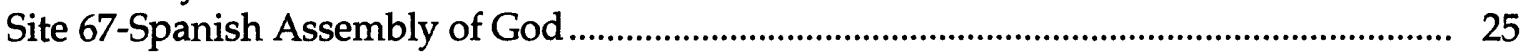

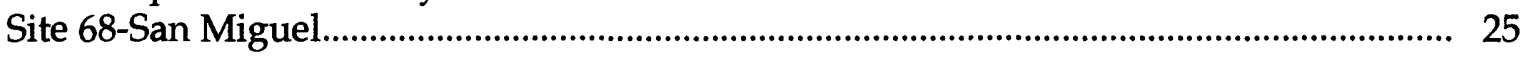

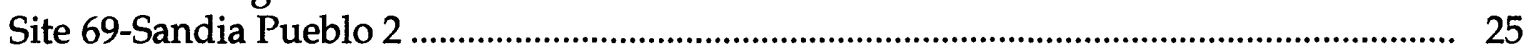

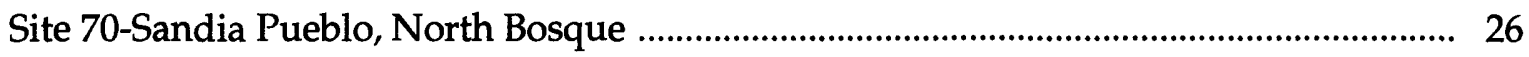

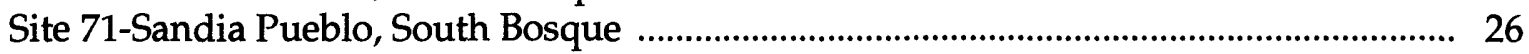

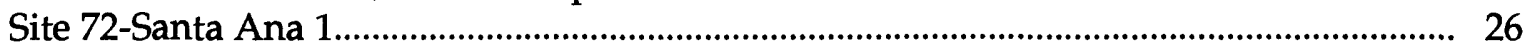

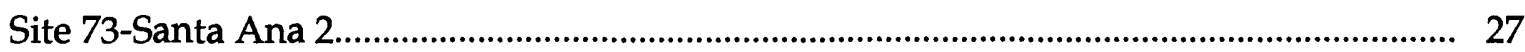

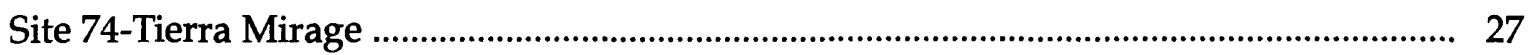

\section{TABLE}

1. Well and piezometer data for the Albuquerque Basin, New Mexico.. 
CONVERSION FACTORS AND VERTICAL DATUM

Multiply

foot

mile

acre
By

0.3048

1.609

4,047
To obtain

meter

kilometer

square meter

Sea level: In this report "sea level" refers to the National Geodetic Vertical Datum of 1929-a geodetic datum derived from a general adjustment of the first-order level nets of the United States and Canada, formerly called Sea Level Datum of 1929. 


\title{
WATER-LEVEL DATA FOR THE ALBUQUERQUE BASIN, NEW MEXICO, PERIOD OF RECORD THROUGH SEPTEMBER 30, 1995
}

\author{
By Dale R. Rankin
}

\begin{abstract}
The Albuquerque Basin, located in central New Mexico, is about 100 miles long and 25 to 40 miles wide. The basin is defined as the extent of Cenozoic deposits that encompass the structural Rio Grande Rift within the basin. Drinking-water supplies throughout the Albuquerque Basin are currently (1996) obtained solely from ground-water resources. The population of the basin grew from 419,000 in 1980 to 563,600 in 1990, a 34-percent increase, and resulted in increases in water demand and ground-water pumpage. Between April 1982 and September 1983, a network of wells was established to monitor changes in ground-water levels throughout the Albuquerque Basin. Water-level data were collected at 74 wells and piezometers for the period of record through September 30, 1995, in the Albuquerque Basin. Water-level data are currently (1996) collected annually at sites 11 and 39; semiannually at sites 1-10; quarterly at sites $12,13,26,36-38,40,43,49-51,64-67,69$, and 71-74; and monthly at sites 14-25, 33-35, 41, 5263 , and 68 .
\end{abstract}

\section{INTRODUCTION}

The Albuquerque Basin is located in central New Mexico and is about 100 miles long and 25 to $\mathbf{4 0}$ miles wide. The basin is defined as the extent of Cenozoic deposits that encompass the structural Rio Grande Rift within the basin (Thorn and others, 1993). The study area extends from Bernalillo south to San Acacia and from Tijeras Canyon west to near the intersection of Interstate 40 and the Bernalillo/Cibola County line (fig. 1). Parts of Sandoval, Bernalillo, Valencia, and Socorro Counties are located within the study area. The only perennial stream is the southward-flowing Rio Grande, which approximately bisects the basin.

The Albuquerque metropolitan area includes a population of 502,100 (U.S. Department of Commerce, 1991). Although the majority of people are concentrated within the Albuquerque city limits, the basinwide population grew from 419,000 in 1980 to 563,600 in 1990 (U.S. Bureau of the Census, 1980, 1991), an increase of 34 percent. The demand for ground water has likewise increased because drinking-water supplies throughout the Albuquerque Basin are currently (1996) obtained solely from ground-water resources (Kues, 1987).

This report provides water-level and other data for 74 selected wells and piezometers in the Albuquerque Basin, central New Mexico (Wilkins, 1986; Anderholm and Bullard, 1987; and Kues, 1987) from the period of record through September 30, 1995. The general location of these wells is shown in figure 1. 


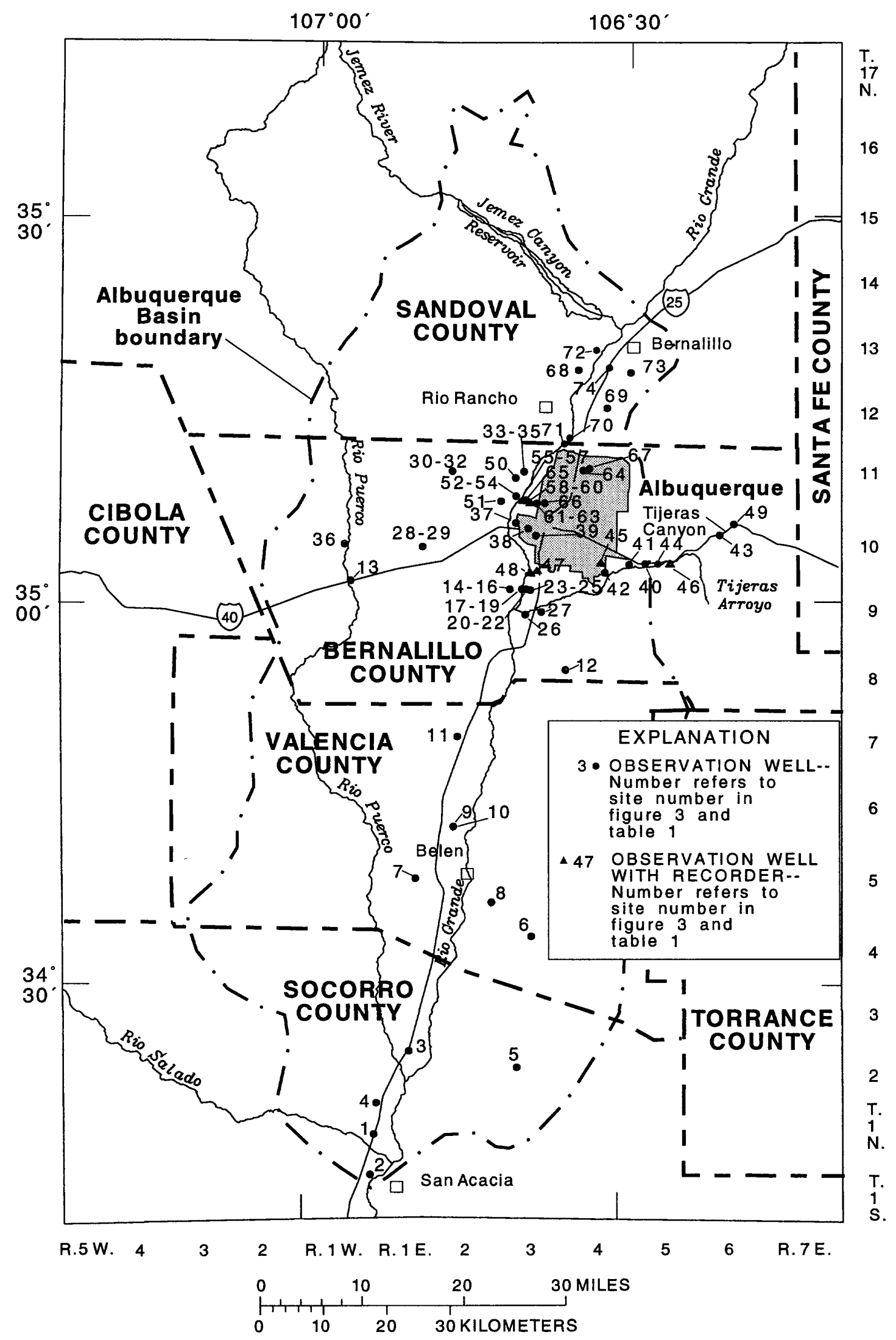

Figure 1.--Location of study area, and observation wells and piezometers. 


\section{Well-Numbering System}

The system of numbering wells in New Mexico is based on the common subdivision of public lands into sections (fig. 2). The well number, in addition to designating the well, locates its position to the nearest 10 -acre tract in the land network. This number is divided into four segments. The first segment denotes the township north of the New Mexico base line, the second denotes the range east of the New Mexico principal meridian, and the third denotes the section. The fourth segment of the number, which consists of three digits, denotes the 160-, 40-, and 10acre tracts, respectively, in which the well is situated. For this purpose, the section is divided into four quarters, numbered 1, 2, 3, and 4, in the normal reading order, for the northwest, northeast, southwest, and southeast quarters. The first digit of the fourth segment gives the quarter section, which is a tract of 160 acres. Similarly, the quarter section is divided into four 40 -acre tracts numbered in the same manner, and the second digit denotes the 40 -acre tract. Finally, the 40 -acre tract is divided into four 10-acre tracts, and the third digit denotes the 10-acre tract. For example, well 09 N.03E.19.243 is in the SW 1/4 of the SE 1/4 of the NE 1/4 of section 19, T. 09 N., R. 03 E. (fig. 2). Letters A, B, C, and so on are added to the last segment of the well number to designate the second, third, fourth, and succeeding wells in the same 10-acre tract.

\section{Methods}

Water-level data were collected by U.S. Geological Survey personnel. Currently (1996), water levels at sites 11 and 39 are measured annually; at sites 1-10, semiannually; at sites 12, 13, 26, 36-38, 40, 43, 49-51, 64-67, 69, and 71-74, quarterly; and at sites 14-25, 33-35, 41, 52-63, and 68, monthly. Electric and steel tapes are used to collect data from sites measured annually, semiannually, quarterly, and monthly; when using tapes, consecutive measurements within 0.02 foot need to be obtained to be considered reliable. Water levels at sites 45, 46, and 48 are monitored hourly with Fischer-Porter analog-to-digital recorders. Sites 27-32, 42, 44, 47, and 70 were dropped from the network in 1994 because of duplication of effort (sites 27 and 42), budget considerations (sites 28-32, 44, and 70), or because the well was destroyed (site 47).

\section{WATER-LEVEL AND OTHER DATA}

Well and piezometer data are listed in table 1. The data in table 1 include site number and identifier, local identifier, owner, other identifier, total depth, and screened interval of the wells and piezometers in the network. Hydrographs of water-level data for the period of record through September 30,1995, are shown in figure 3. The name shown on each hydrograph in figure 3 refers to the "other identifier" column in table 1 . For wells for which "other identifier" is not available, the well name refers to the well owner. The data presented in the hydrographs include depth to water, in feet below land surface, and hydraulic head, in feet above sea level. Hydraulic head is the altitude of the water level. Recorded data are incomplete for some wells or piezometers because of recorder malfunction or temporary removal of the recorder when waterquality samples were obtained. The total depth of wells and piezometers range from 8 to 1,800 feet below land surface. Sites 1-4, 6-10, 13, 26, 50, 51, 64, 67, 68, and 74 are domestic wells; sites 5 , 14-25, 27-35, 37-49, 52-63, 65, 66, and 70-73 are observation wells or piezometers; sites 2 and 11 are irrigation wells; and sites 12,36 , and 69 are stock wells. 


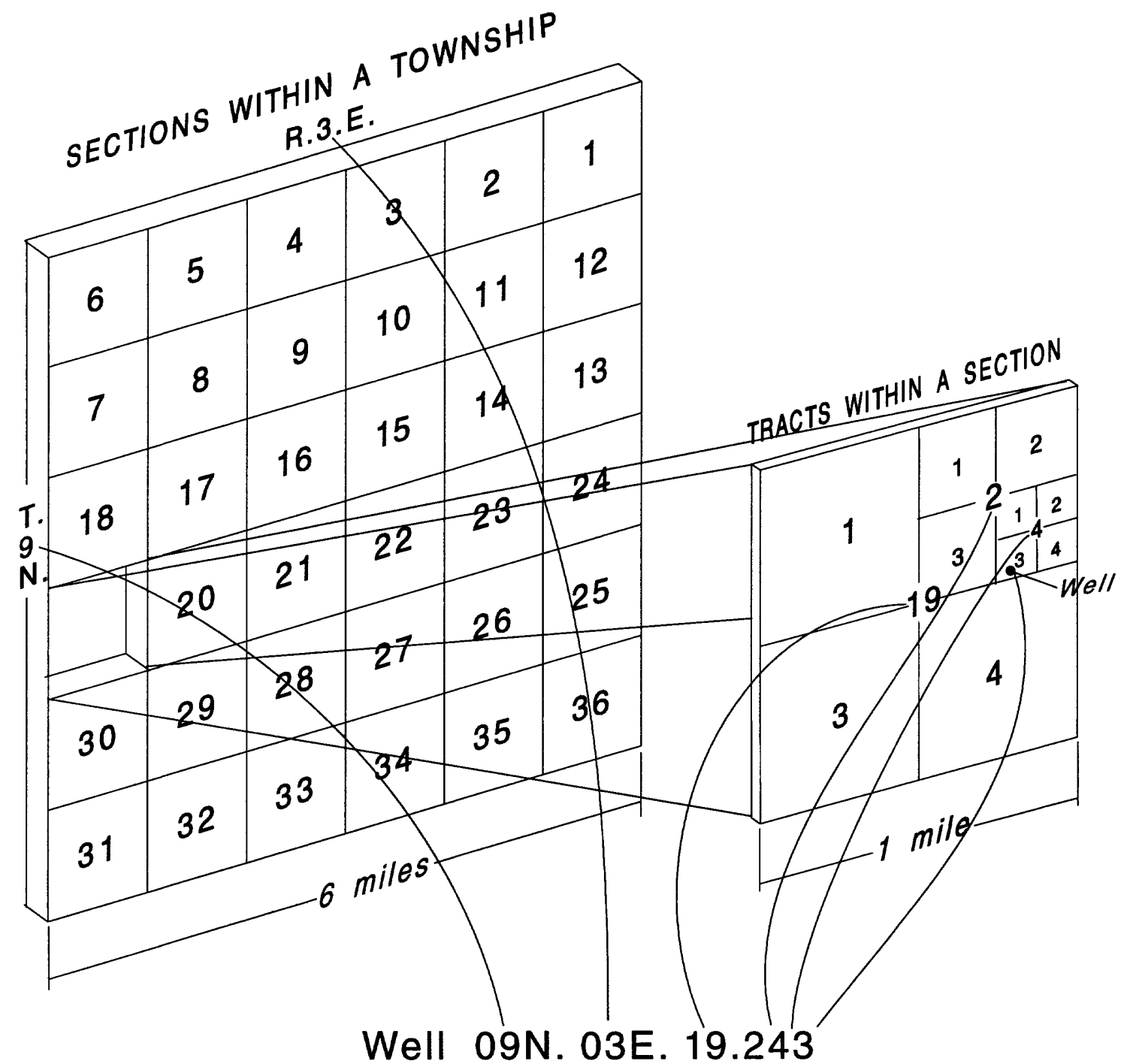

Figure 2.--Well-numbering system in New Mexico. 


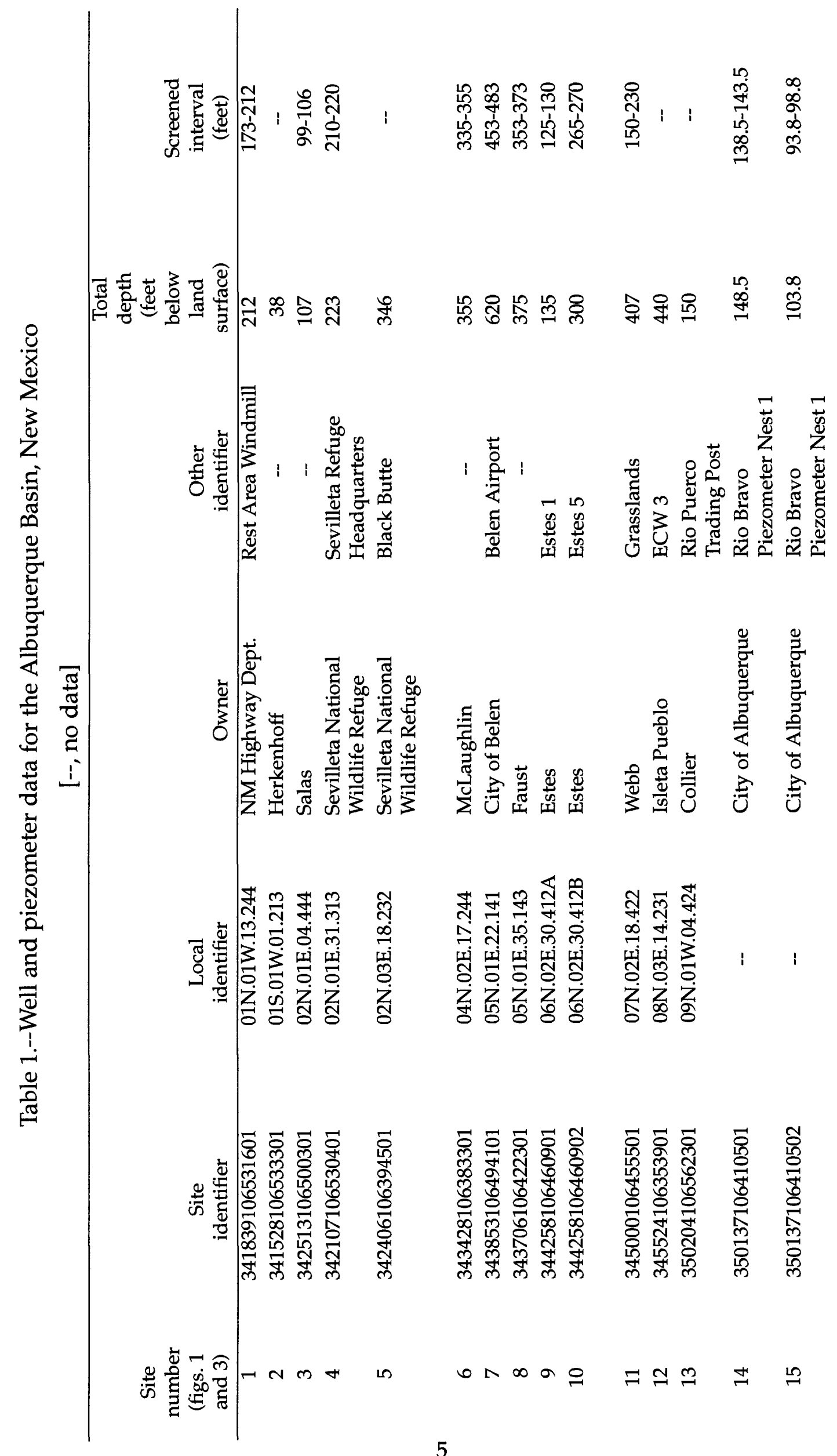




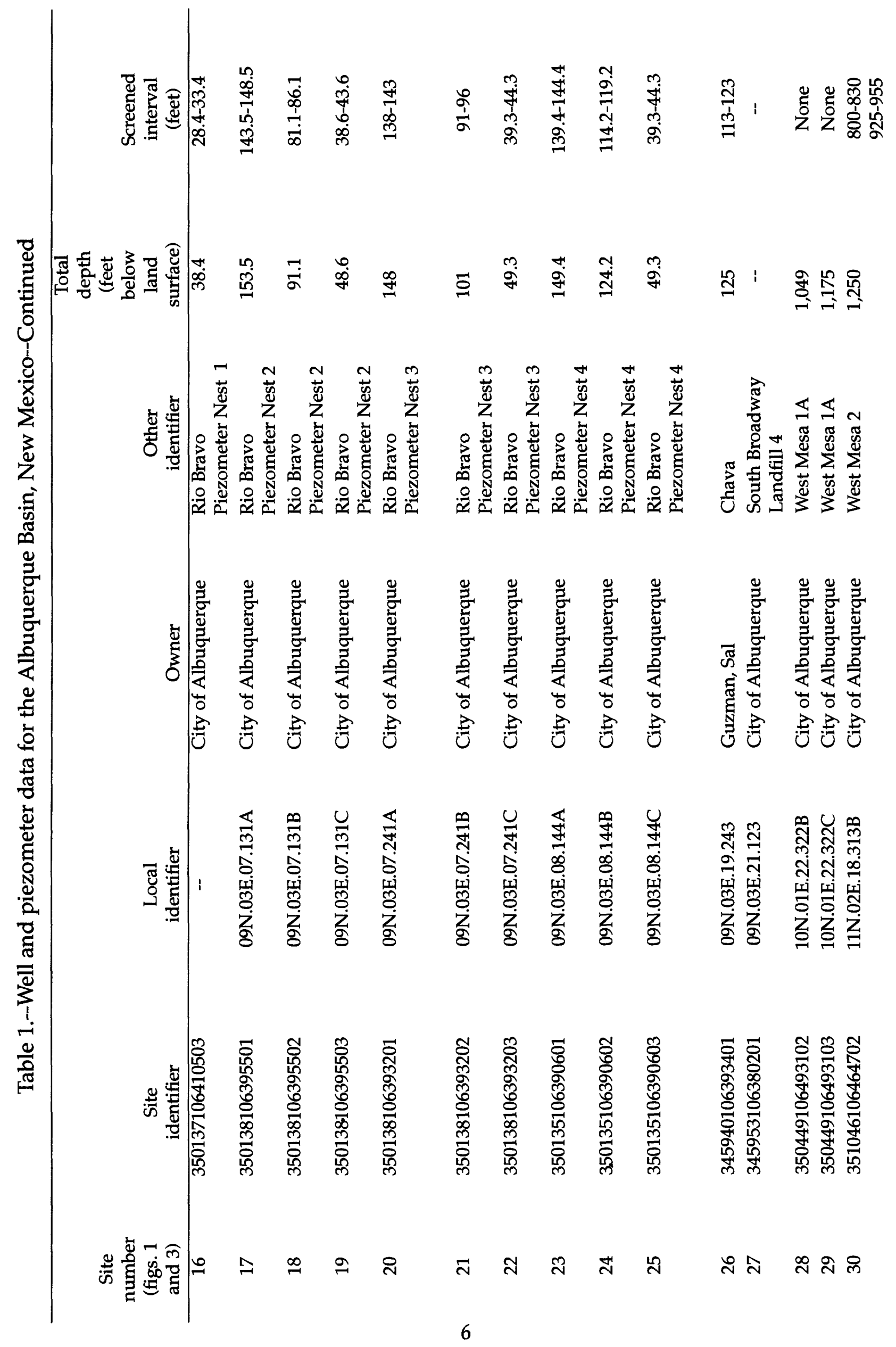




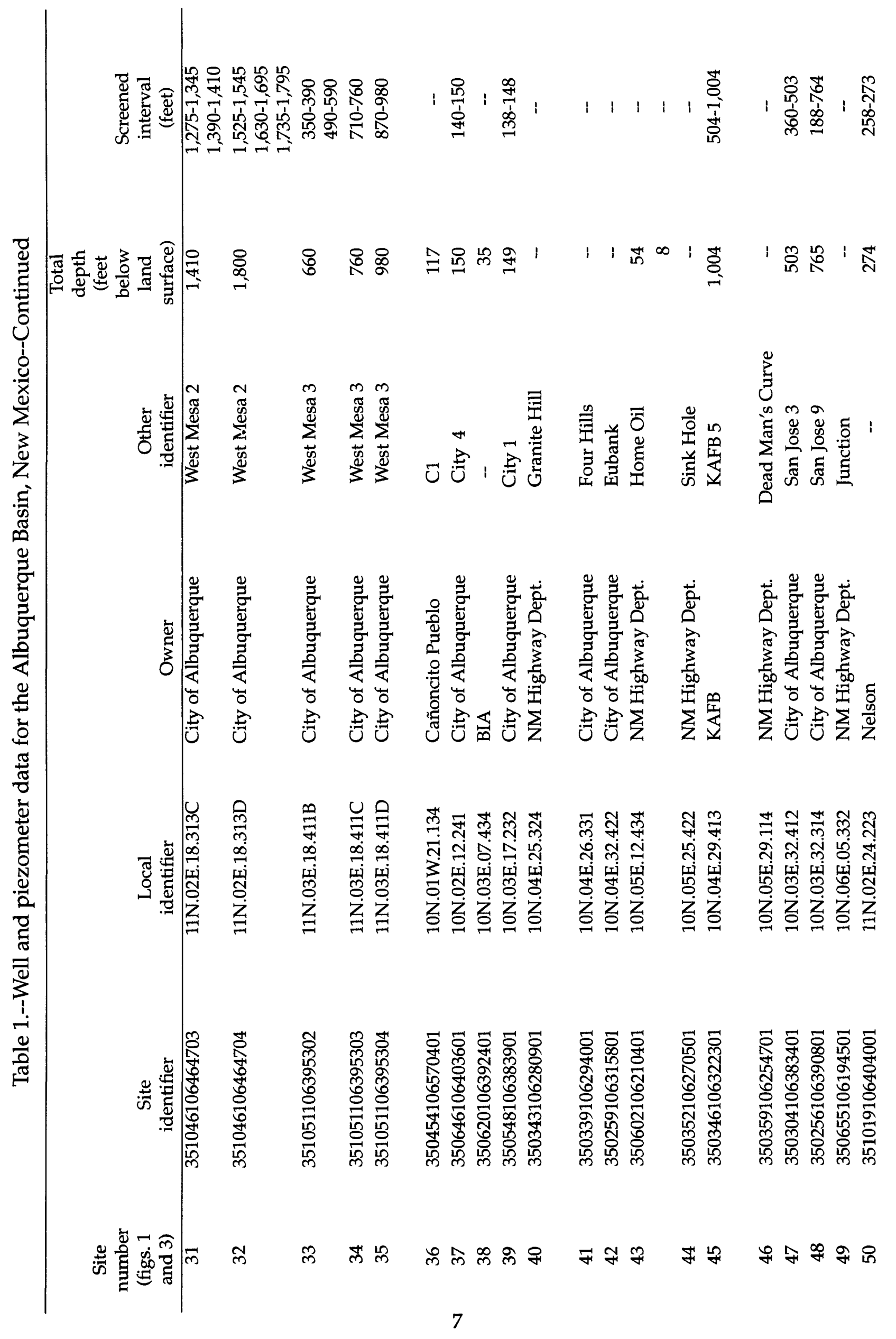




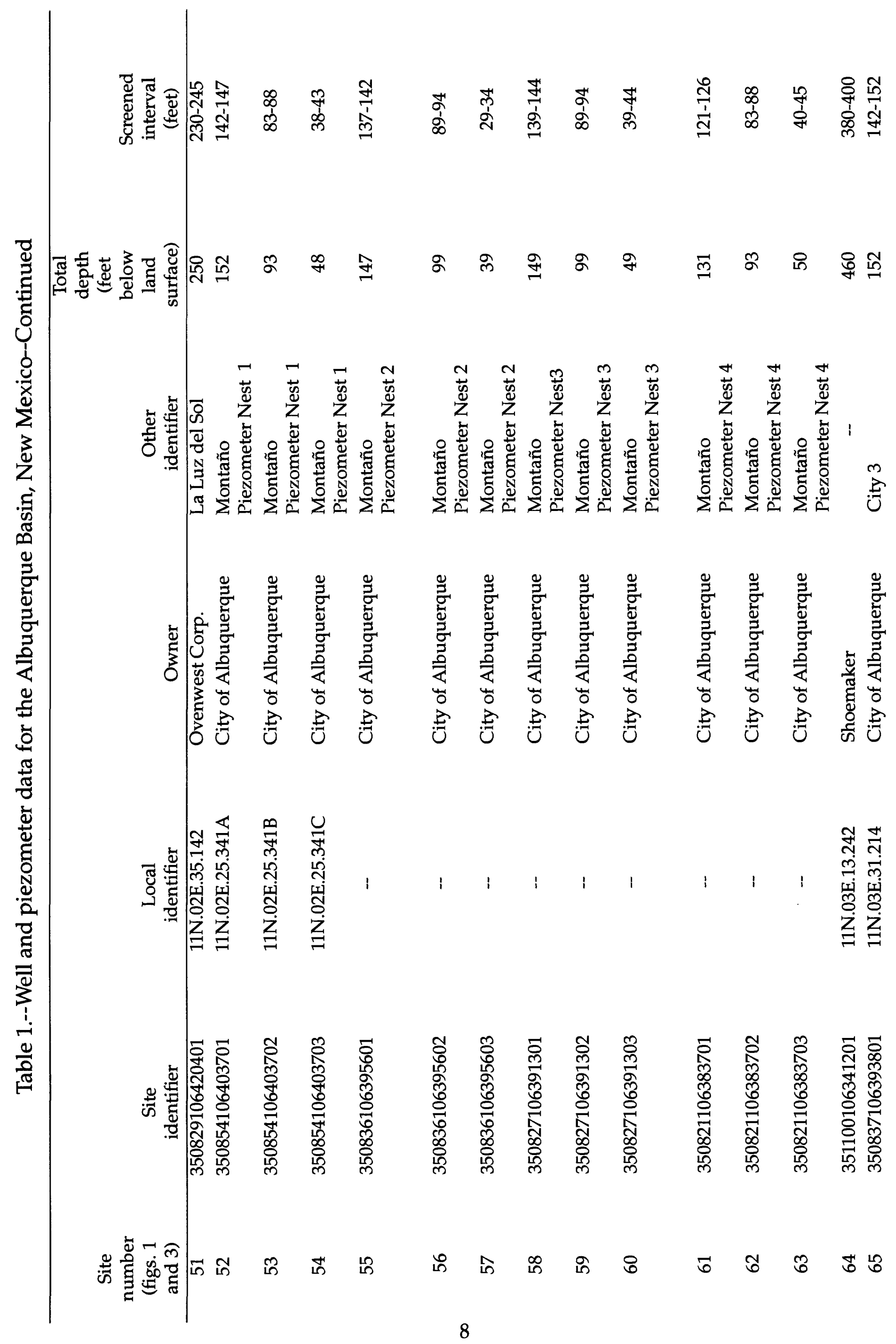




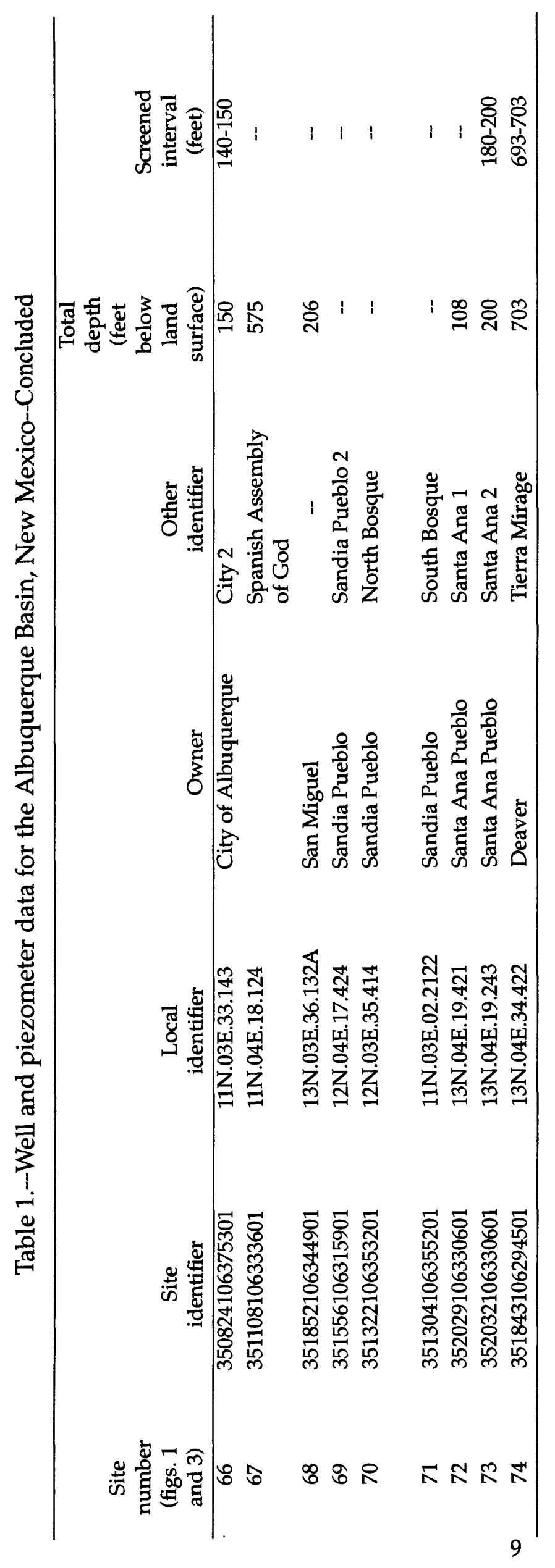


Site 1-Rest Area Windmill

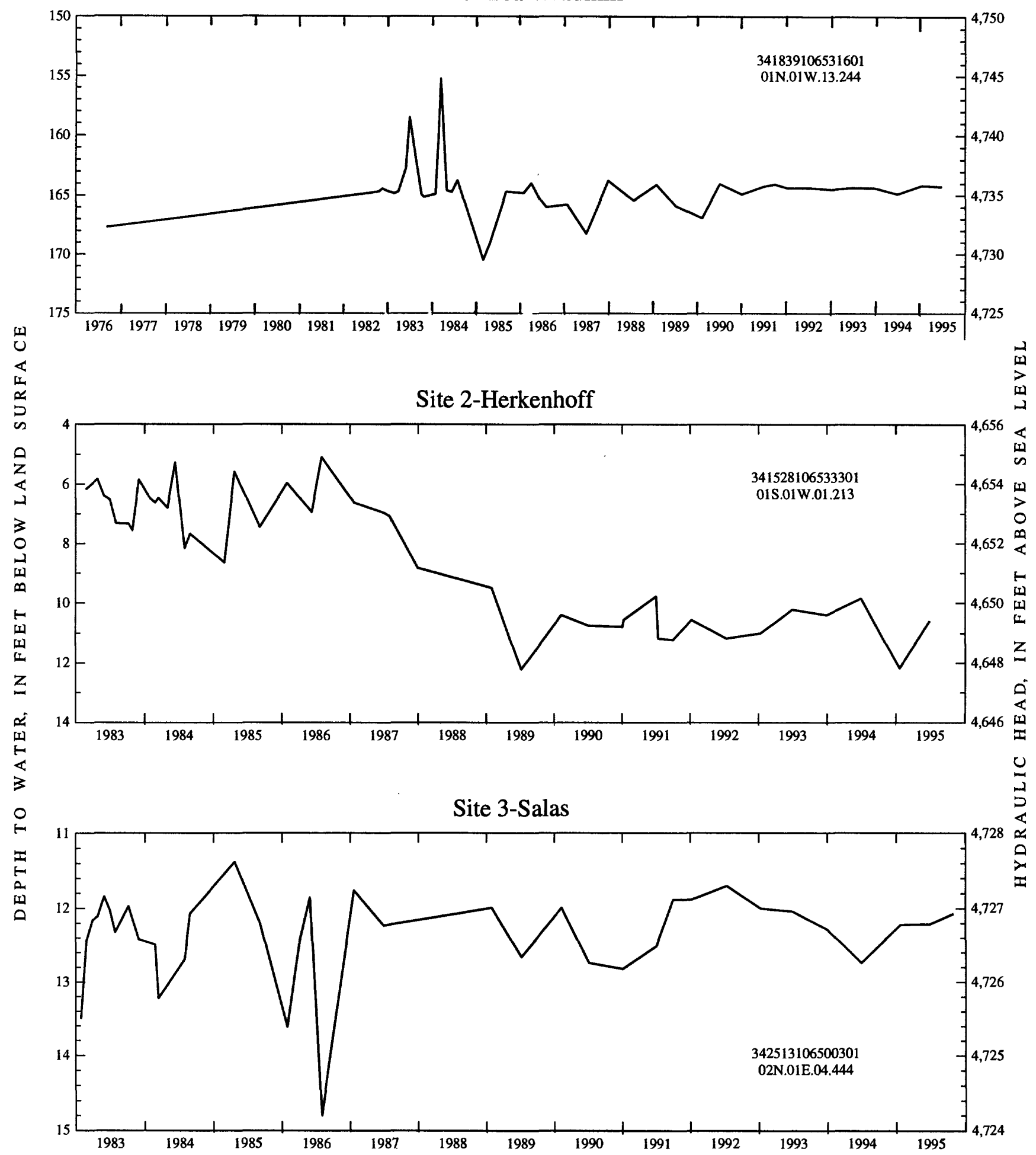

Figure 3.--Water-level data for selected wells and piezometers in the Albuquerque Basin. 
Site 4-Sevilleta Refuge Headquarters

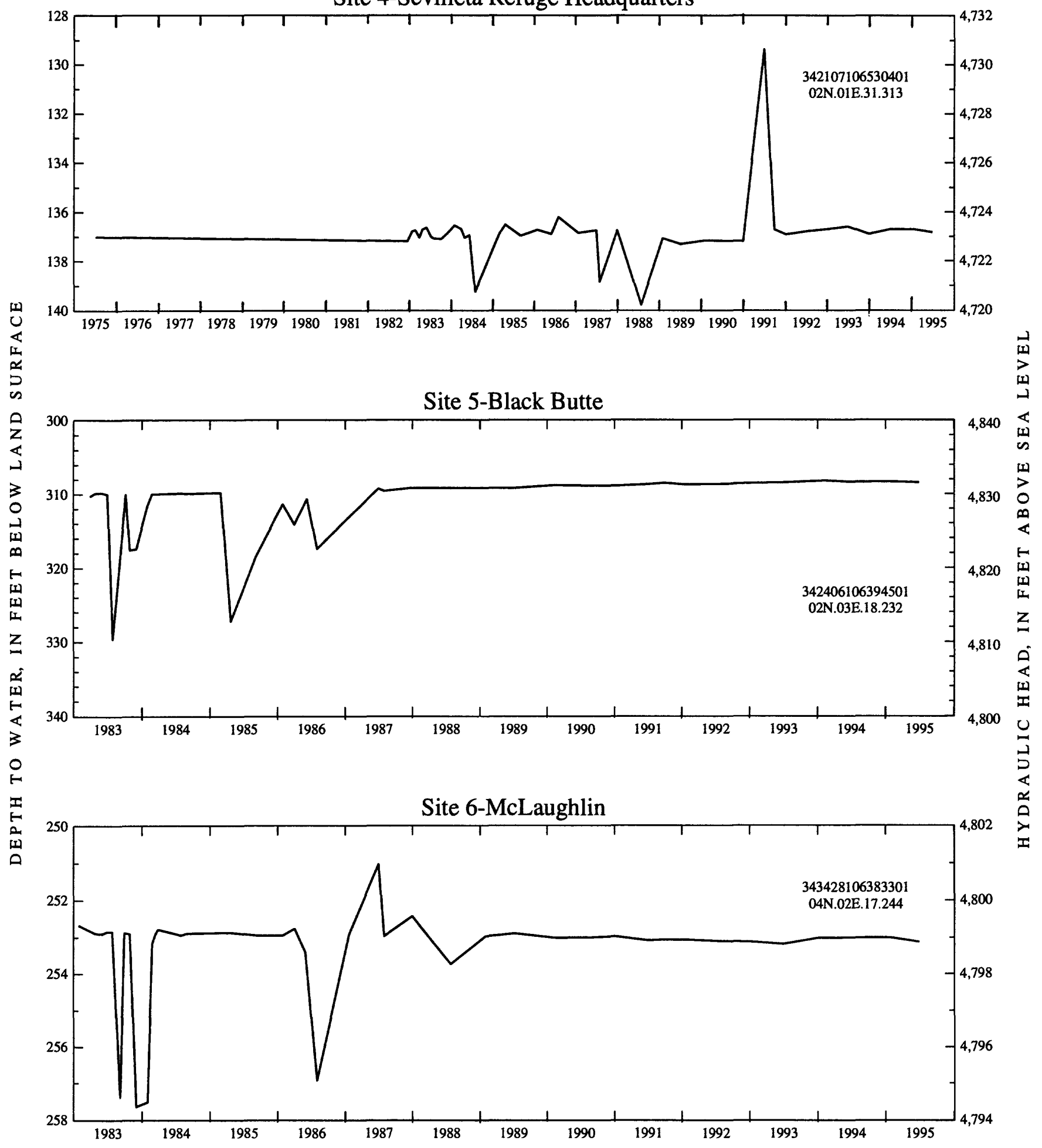

Figure 3.--Water-level data for selected wells and piezometers in the Albuquerque Basin--Continued. 
Site 7-Belen Airport

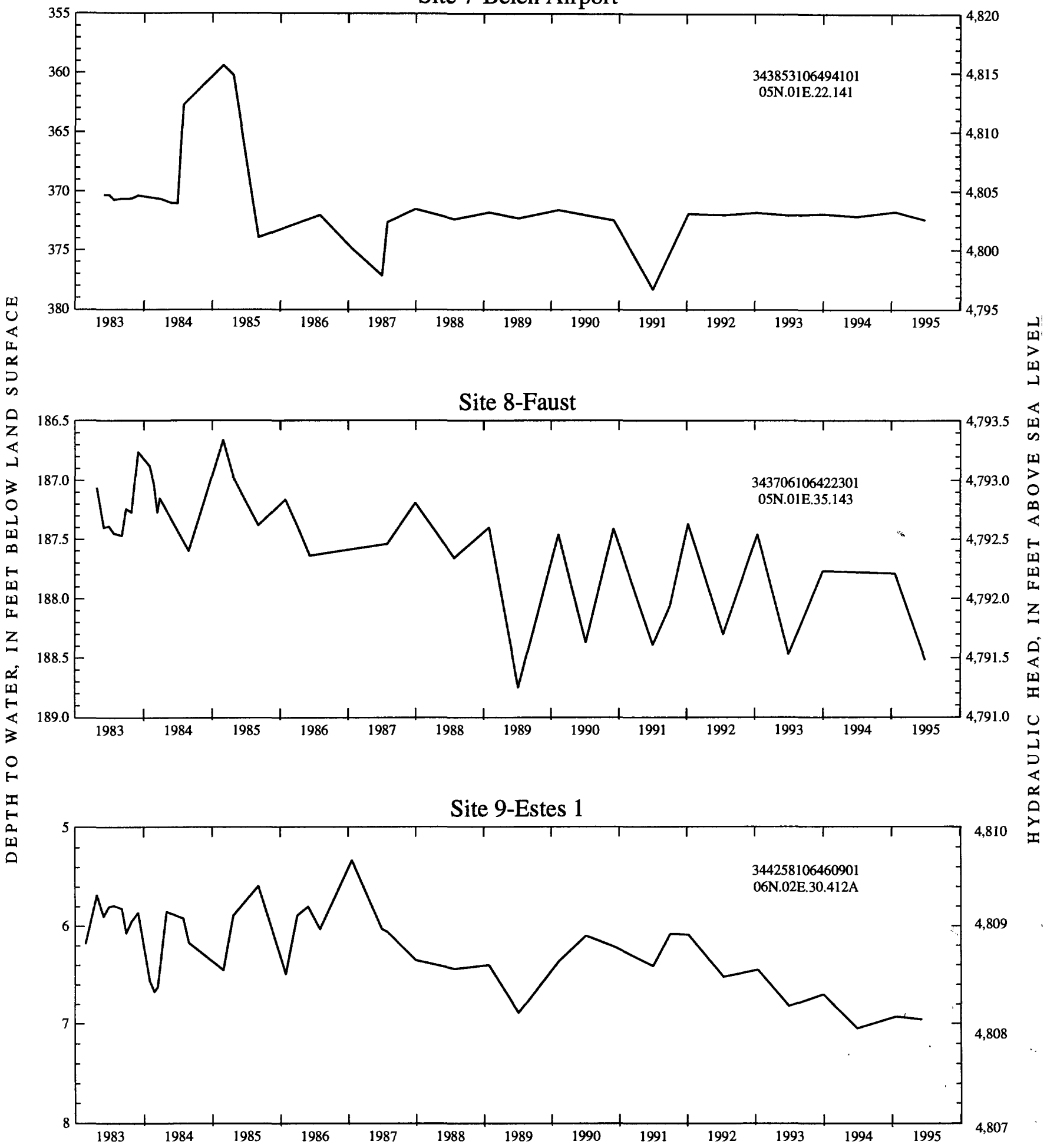

Figure 3.--Water-level data for selected wells and piezometers in the Albuquerque Basin--Continued. 
Site 10-Estes 5

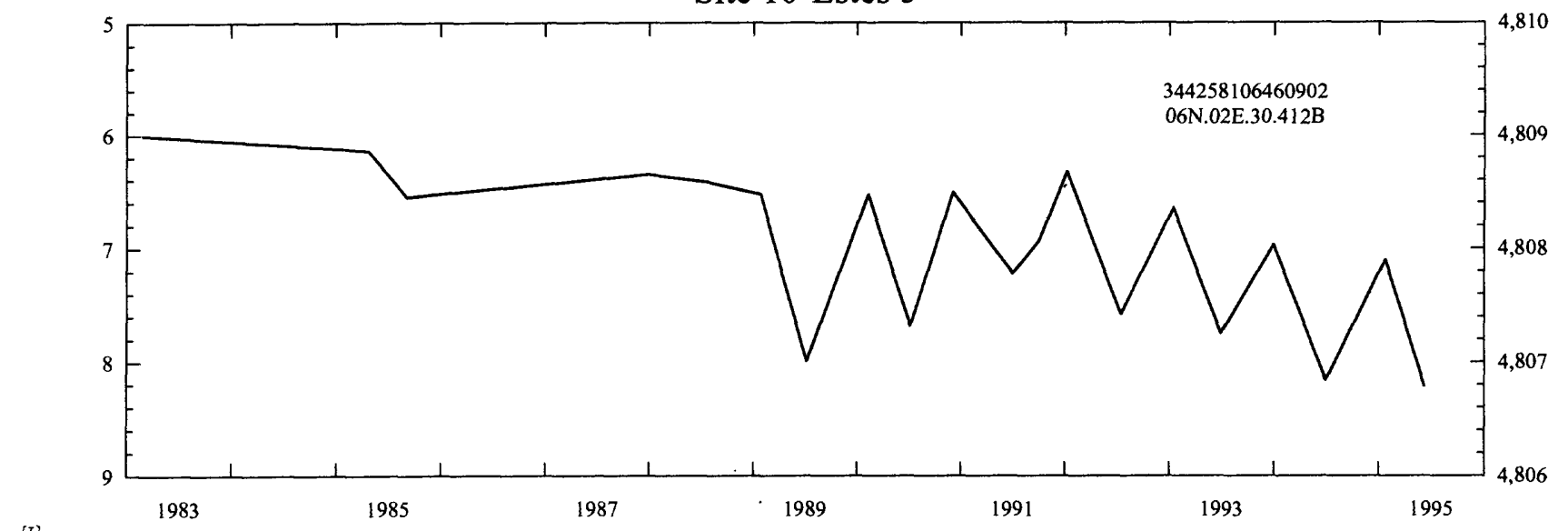

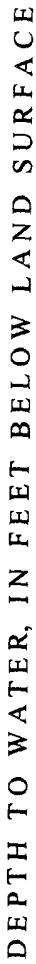

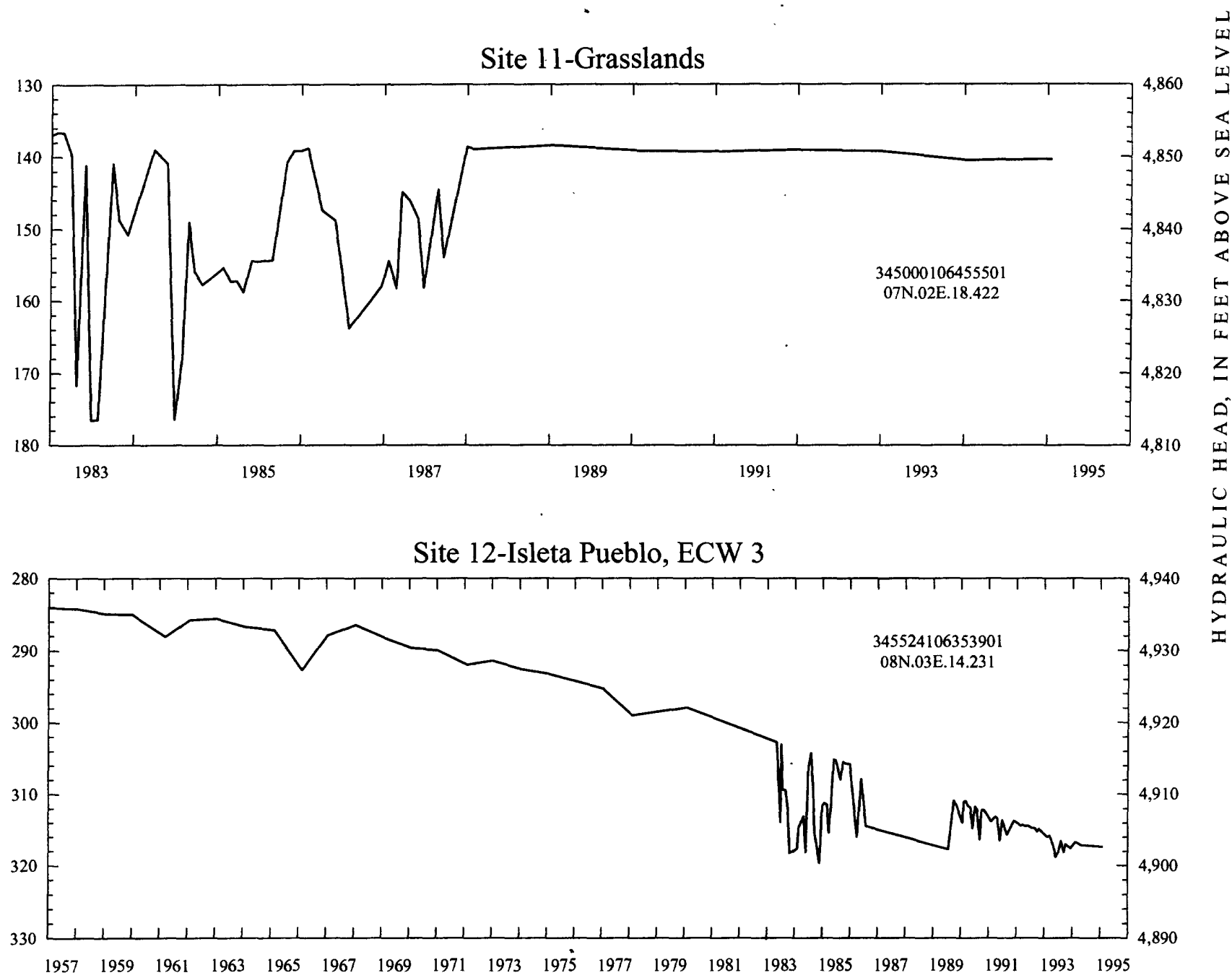

Figure 3.--Water-level data for selected wells and piezometers in the Albuquerque Basin--Continued. 
Site 13-Rio Puerco Trading Post

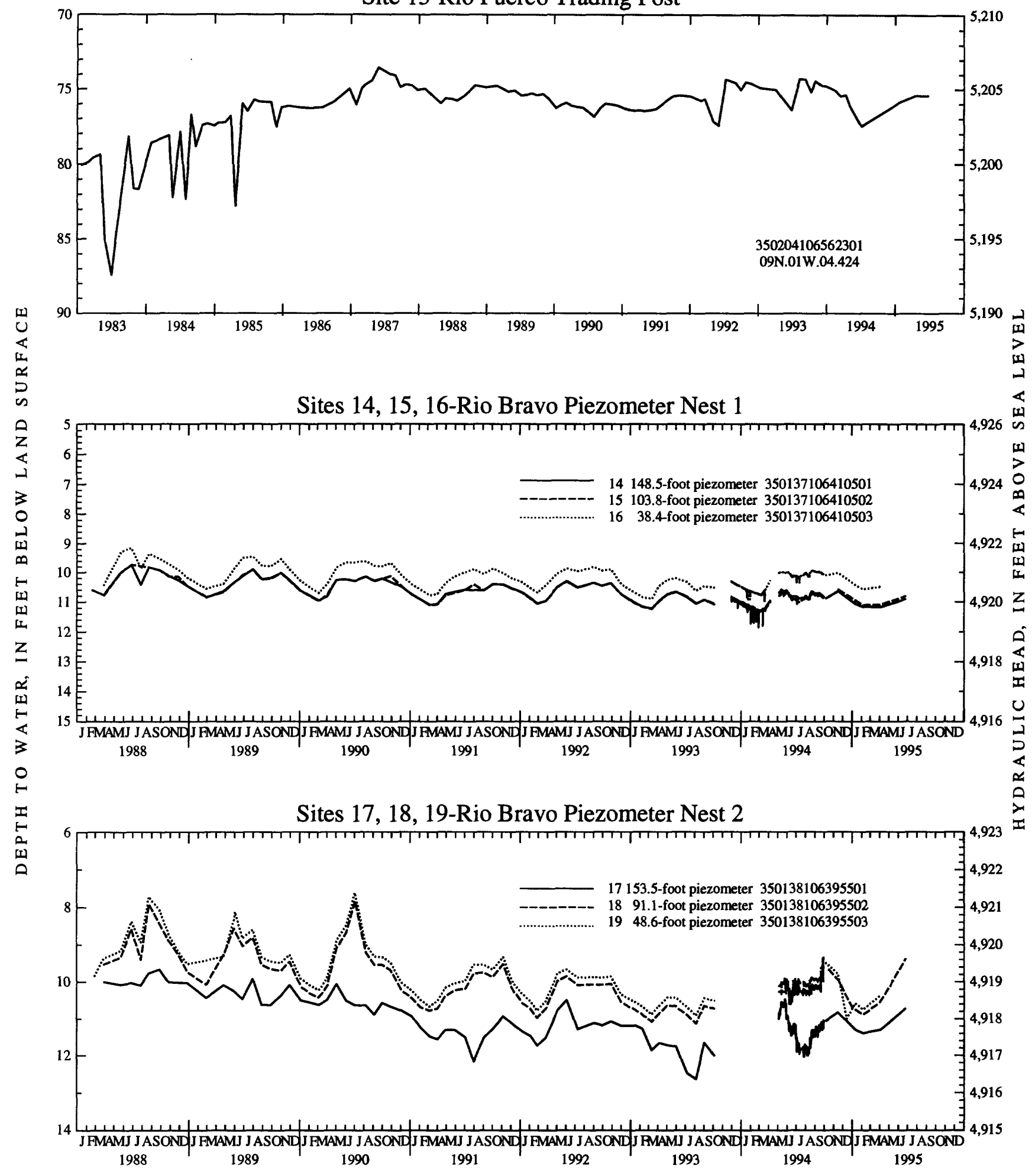

Figure 3.--Water-level data for selected wells and piezometers in the Albuquerque Basin--Continued. 
Sites 20, 21, 22-Rio Bravo Piezometer Nest 3

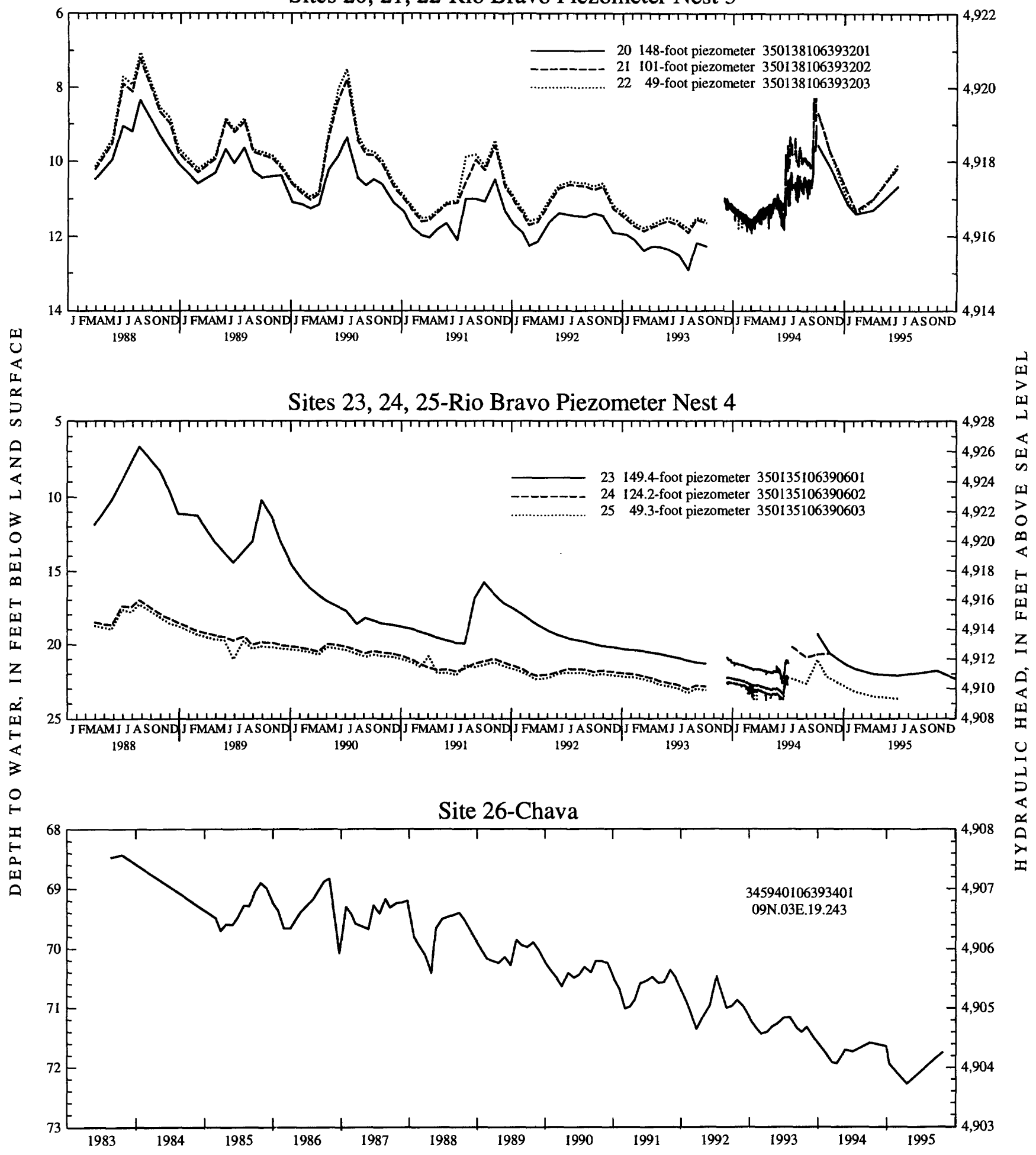

Figure 3.--Water-level data for selected wells and piezometers in the Albuquerque Basin--Continued. 
Site 27-South Broadway Landfill 4

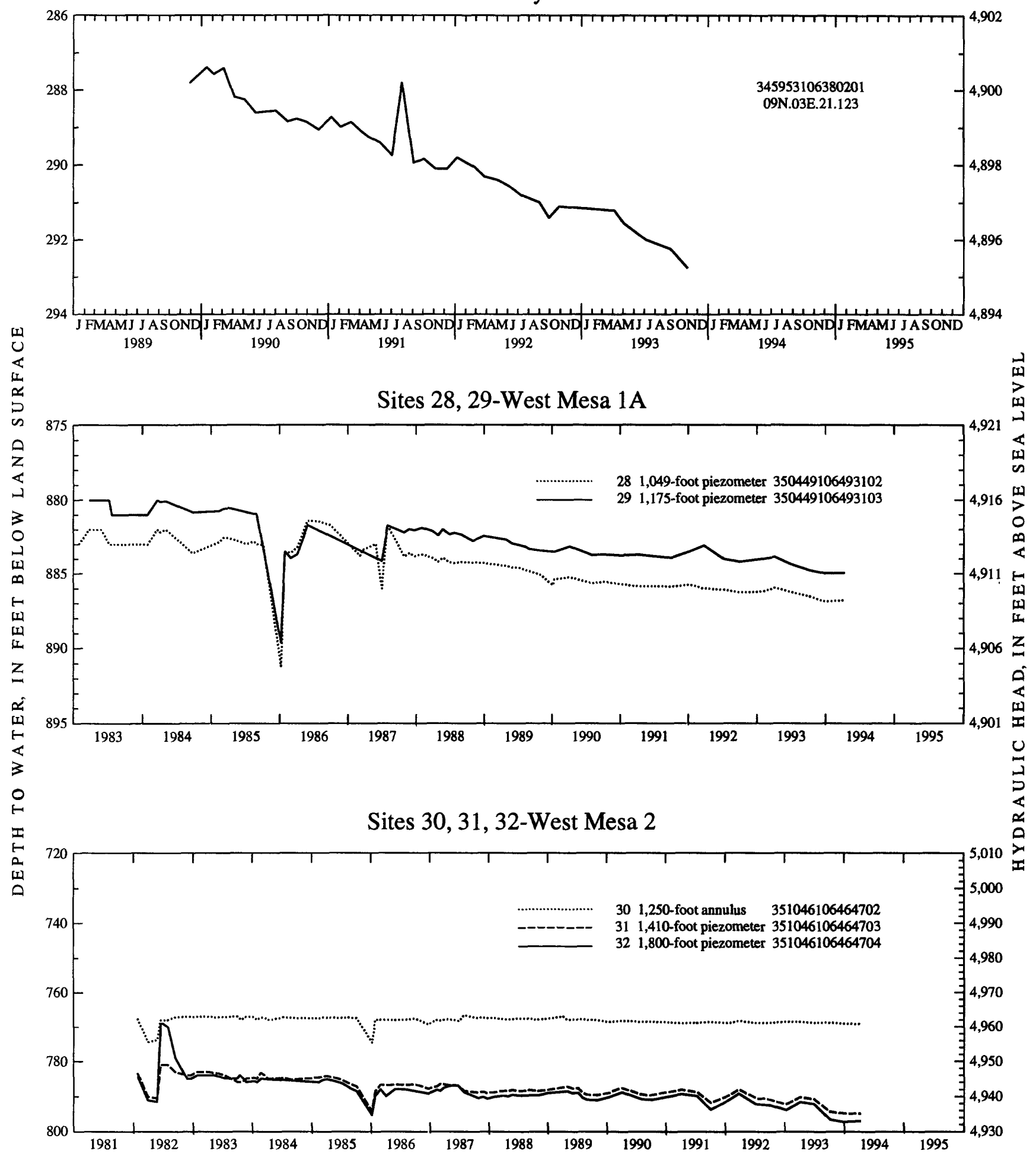

Figure 3.--Water-level data for selected wells and piezometers in the Albuquerque Basin--Continued. 
Sites 33, 34, 35-West Mesa 3
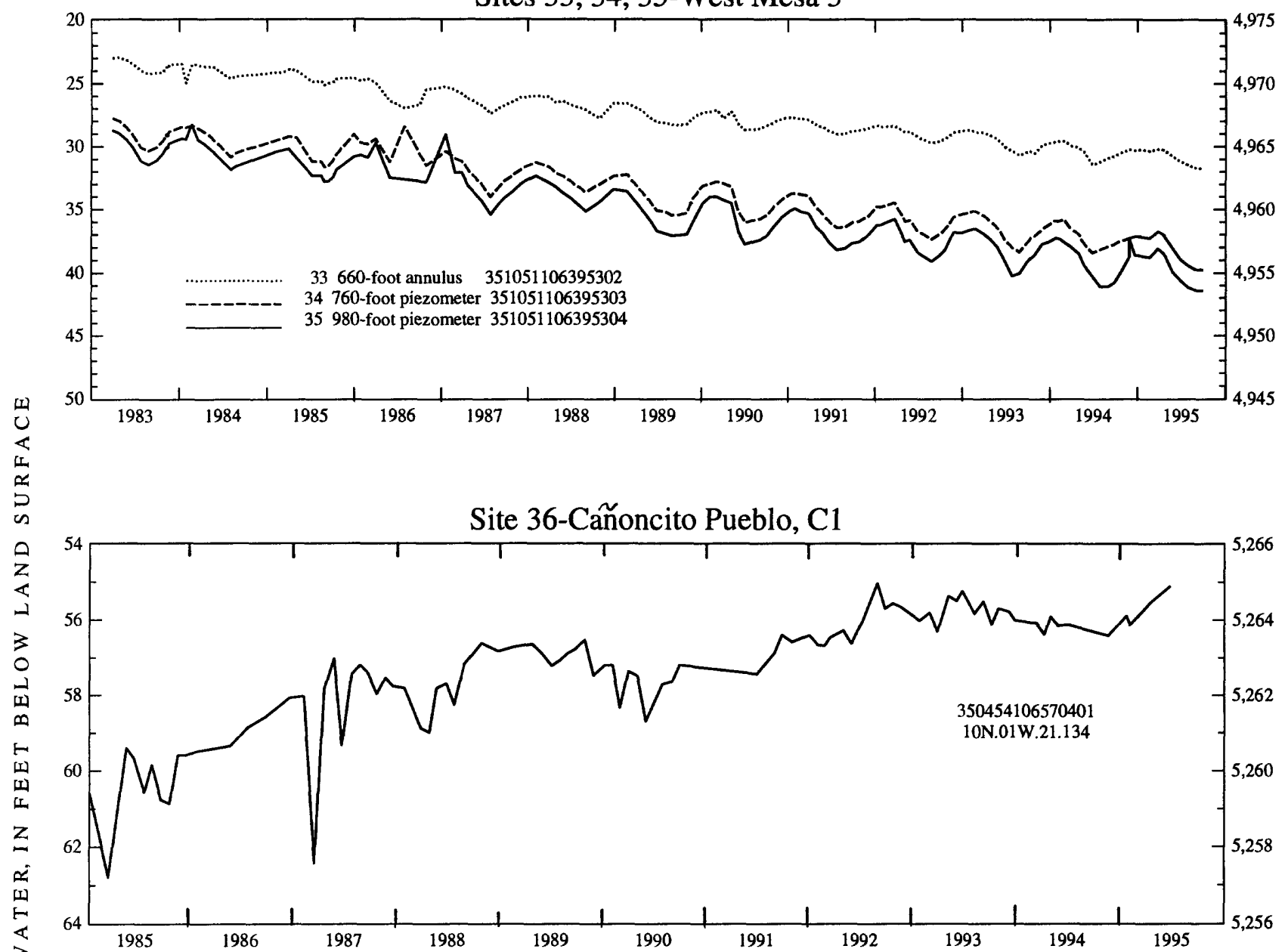

3

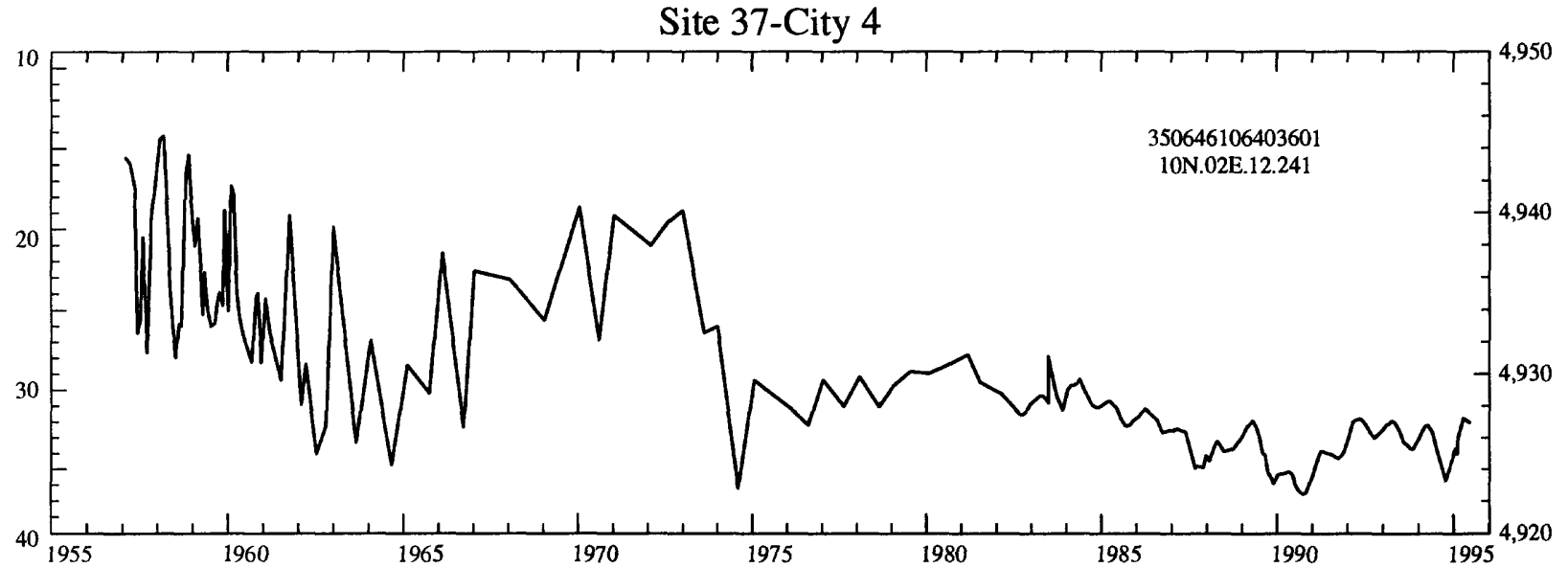

Figure 3.--Water-level data for selected wells and piezometers in the Albuquerque Basin--Continued. 
Site 38-BIA

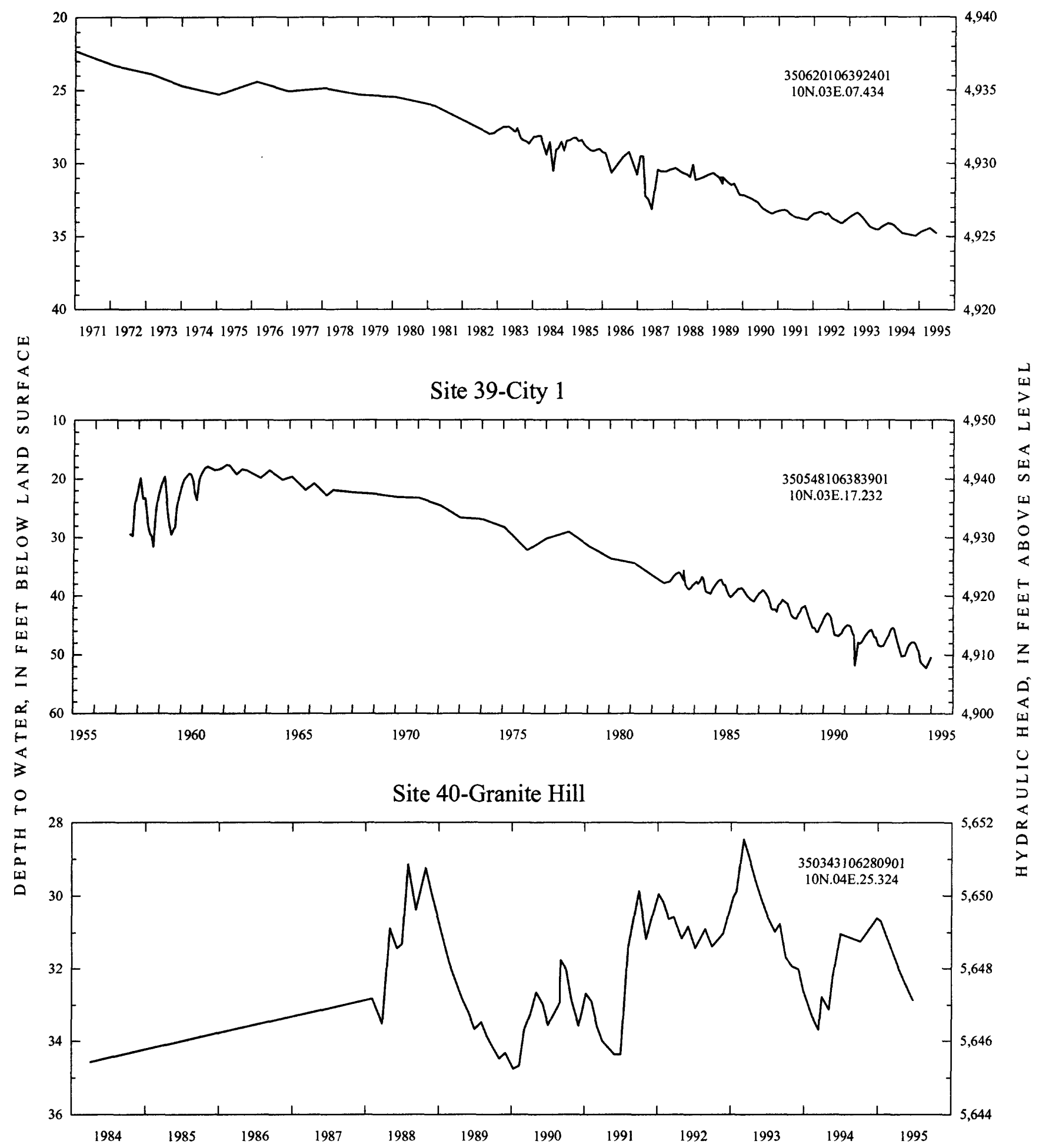

Figure 3.--Water-level data for selected wells and piezometers in the Albuquerque Basin--Continued. 
Site 41-Four Hills

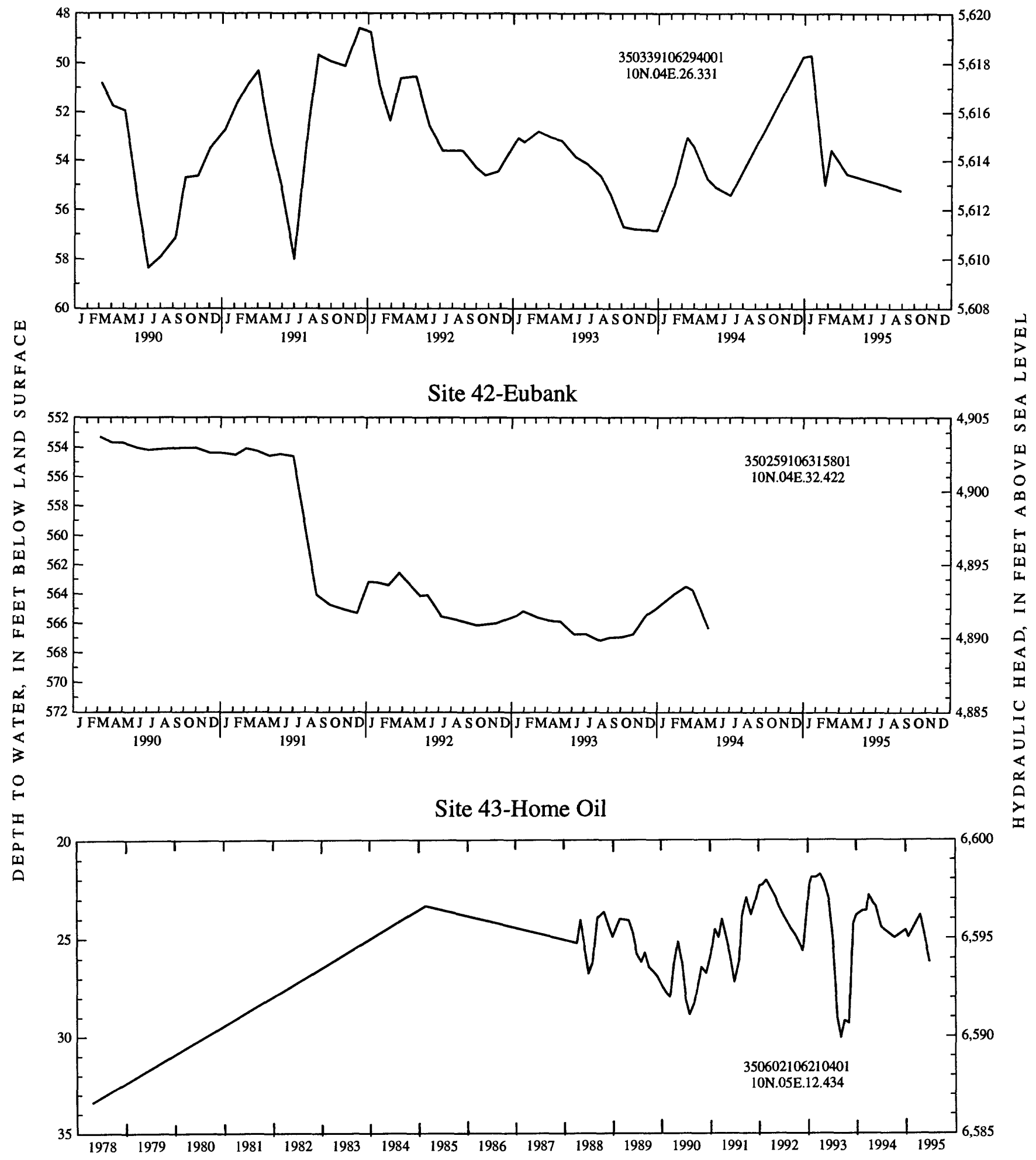

Figure 3.--Water-level data for selected wells and piezometers in the Albuquerque Basin--Continued. 
Site 44-Sink Hole

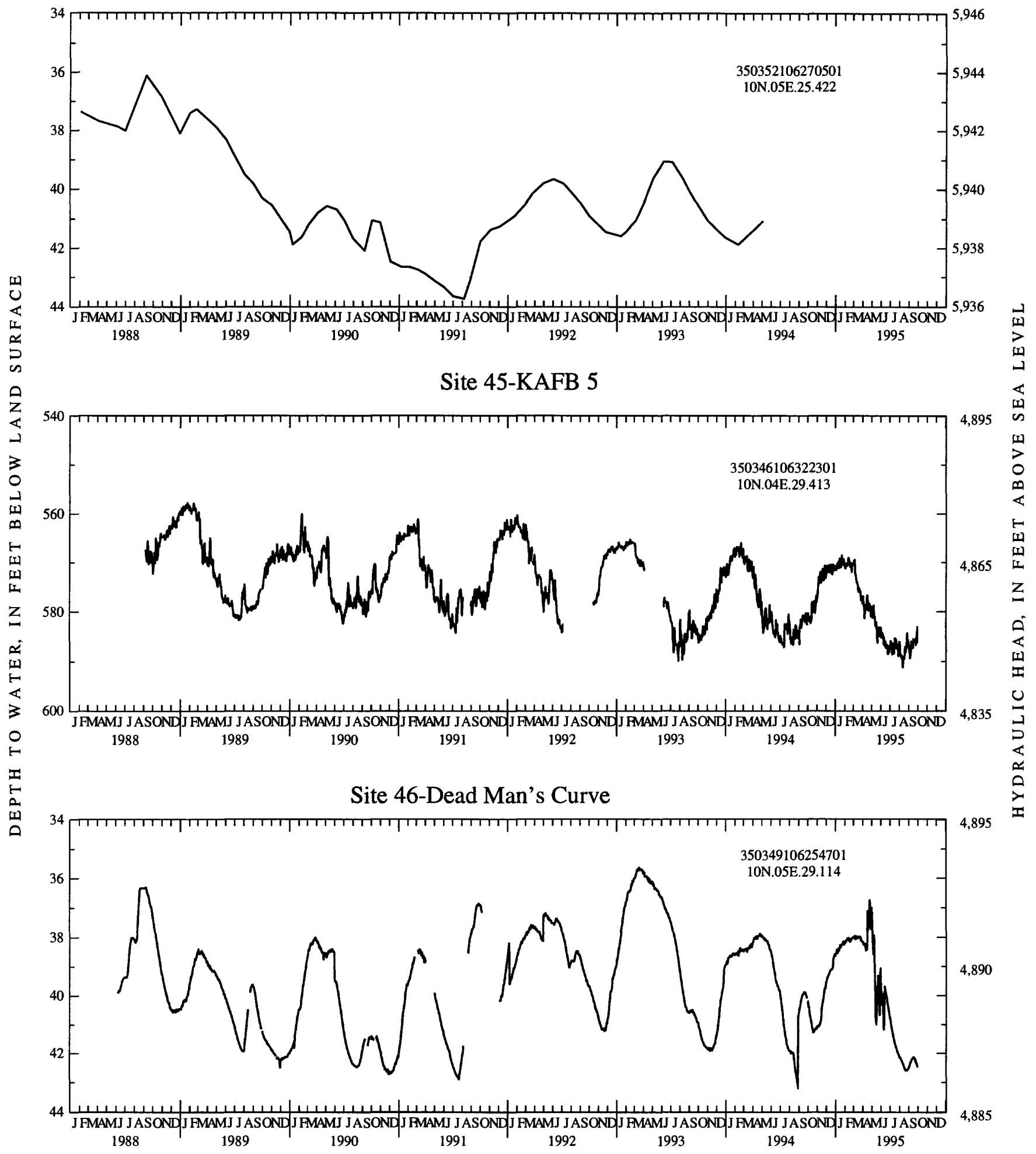

Figure 3.--Water-level data for selected wells and piezometers in the Albuquerque Basin--Continued. 
Site 47-San Jose 3

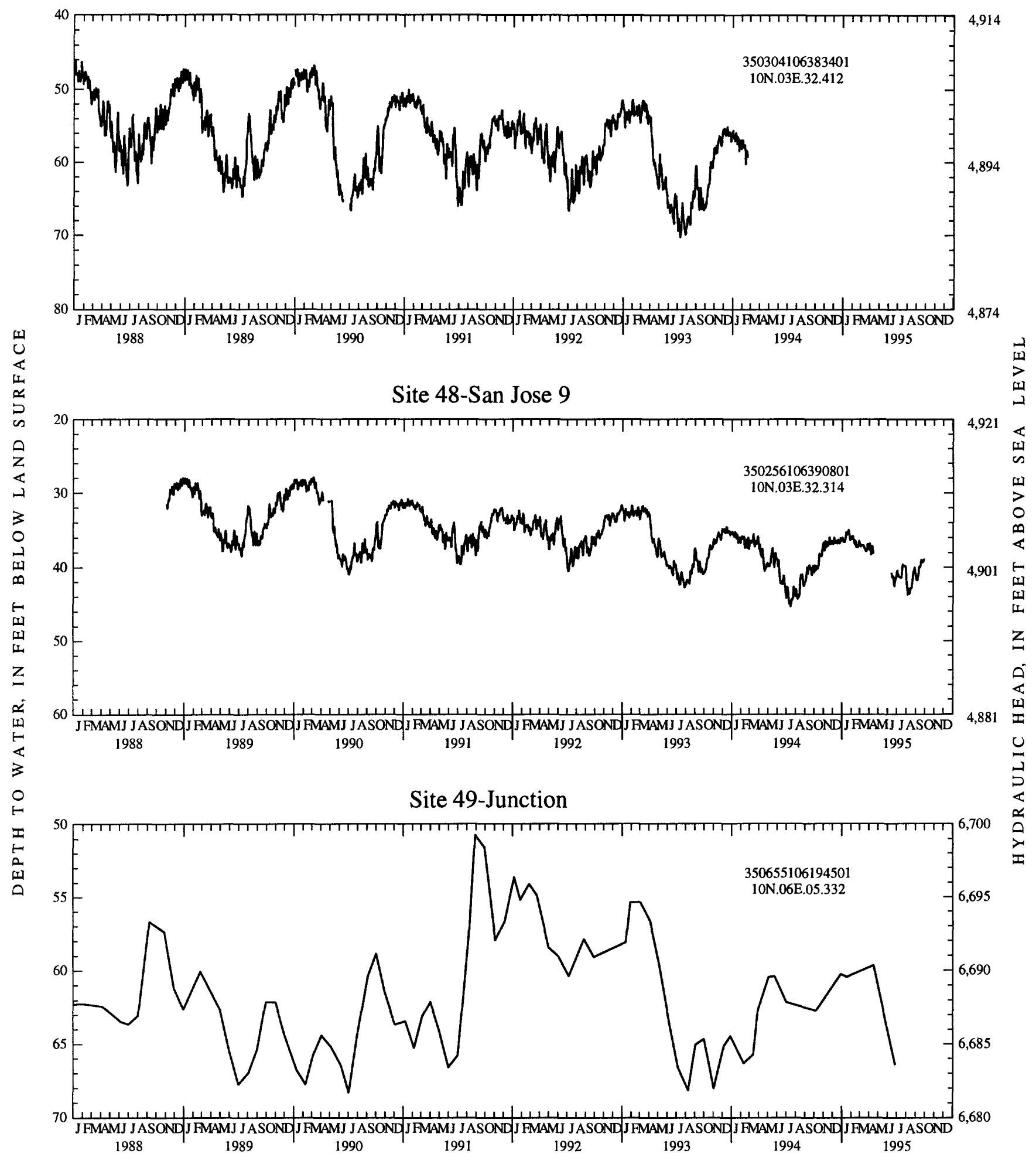

Figure 3.--Water-level data for selected wells and piezometers in the Albuquerque Basin--Continued. 
Site 50-Nelson

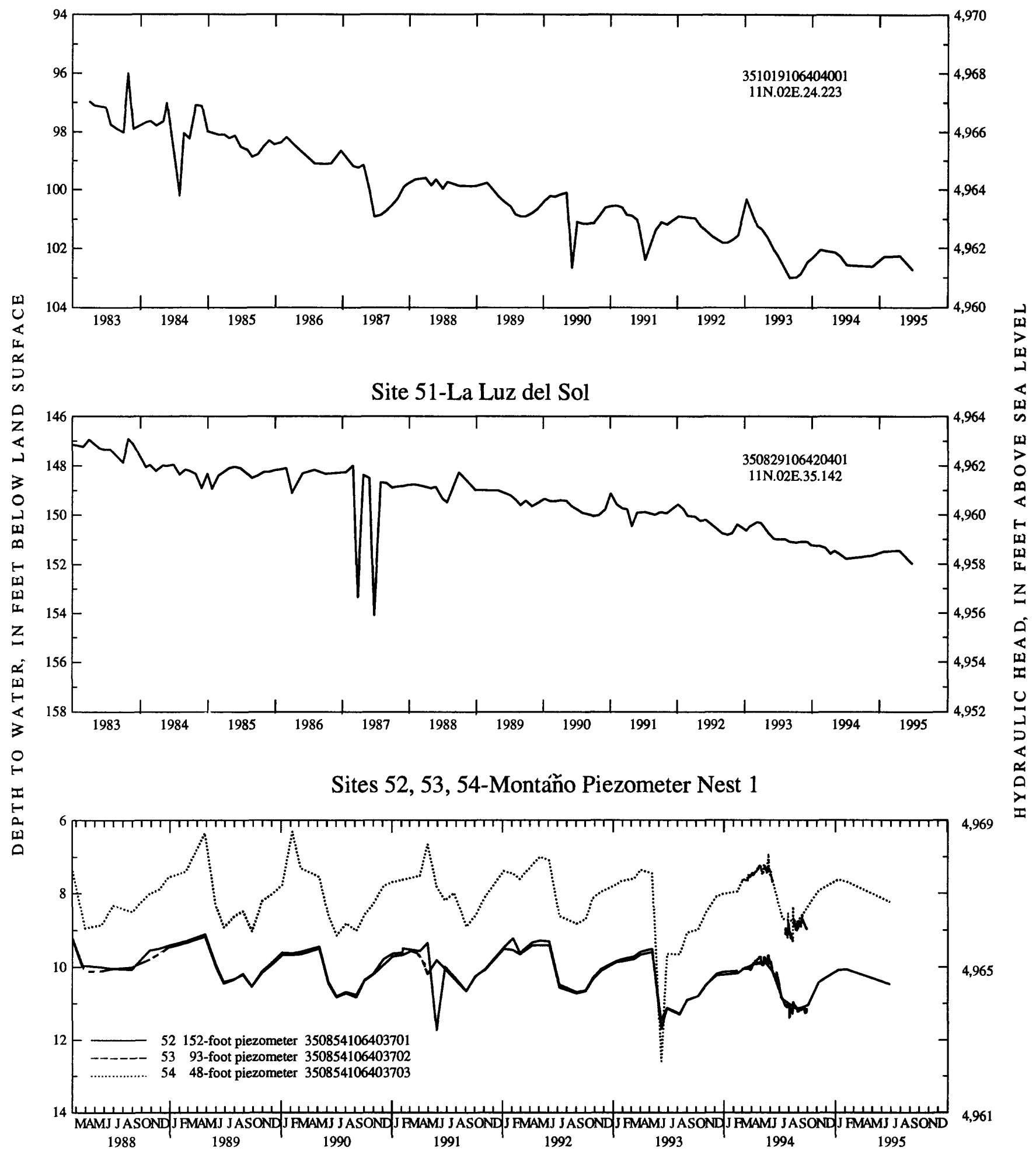

Figure 3.--Water-level data for selected wells and piezometers in the Albuquerque Basin--Continued. 
Sites 55, 56, 57-Montaño Piezometer Nest 2

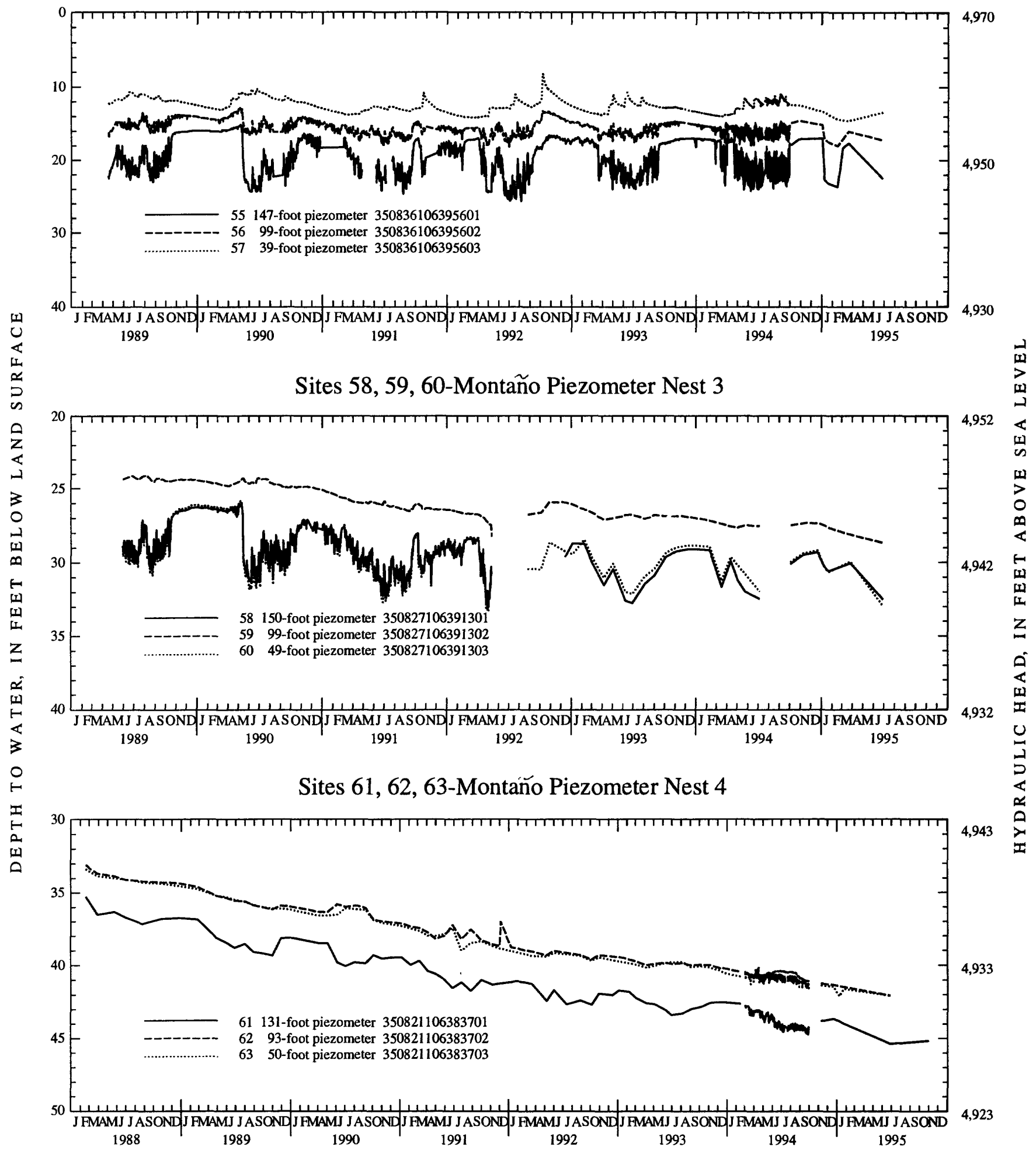

Figure 3.--Water-level data for selected wells and piezometers in the Albuquerque Basin--Continued. 
Site 64-Shoemaker

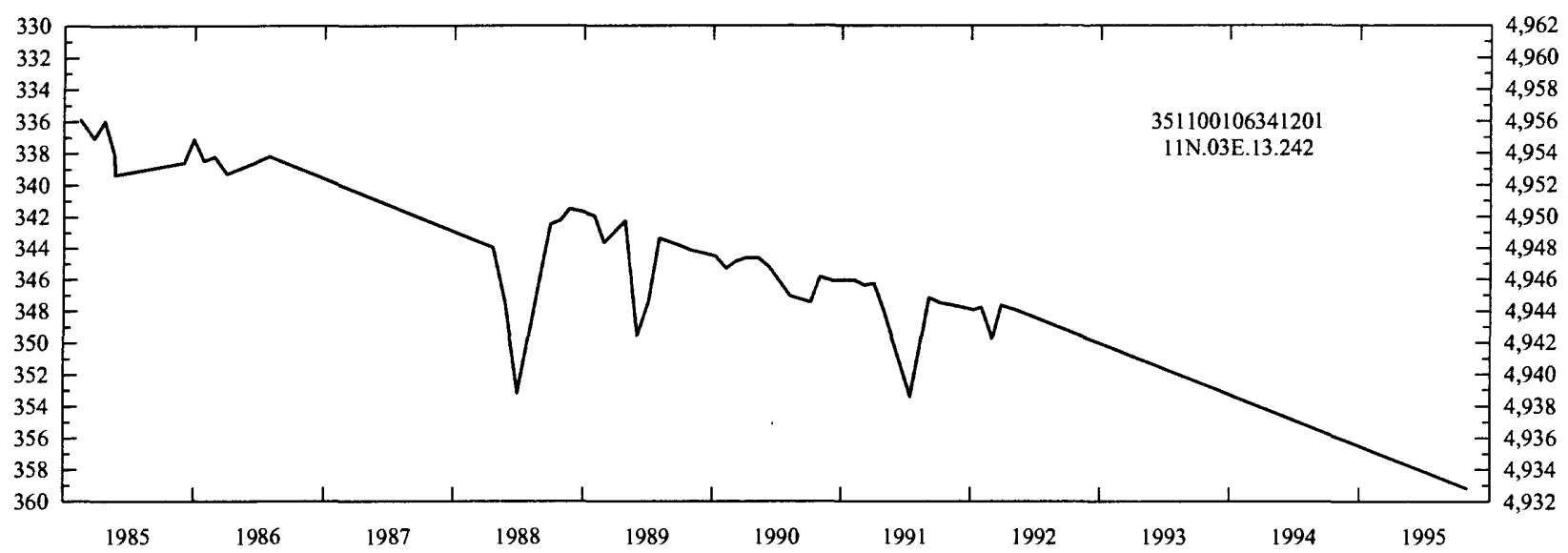

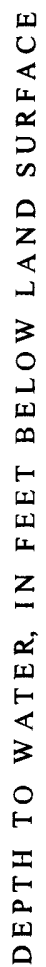

Site 65-City 3

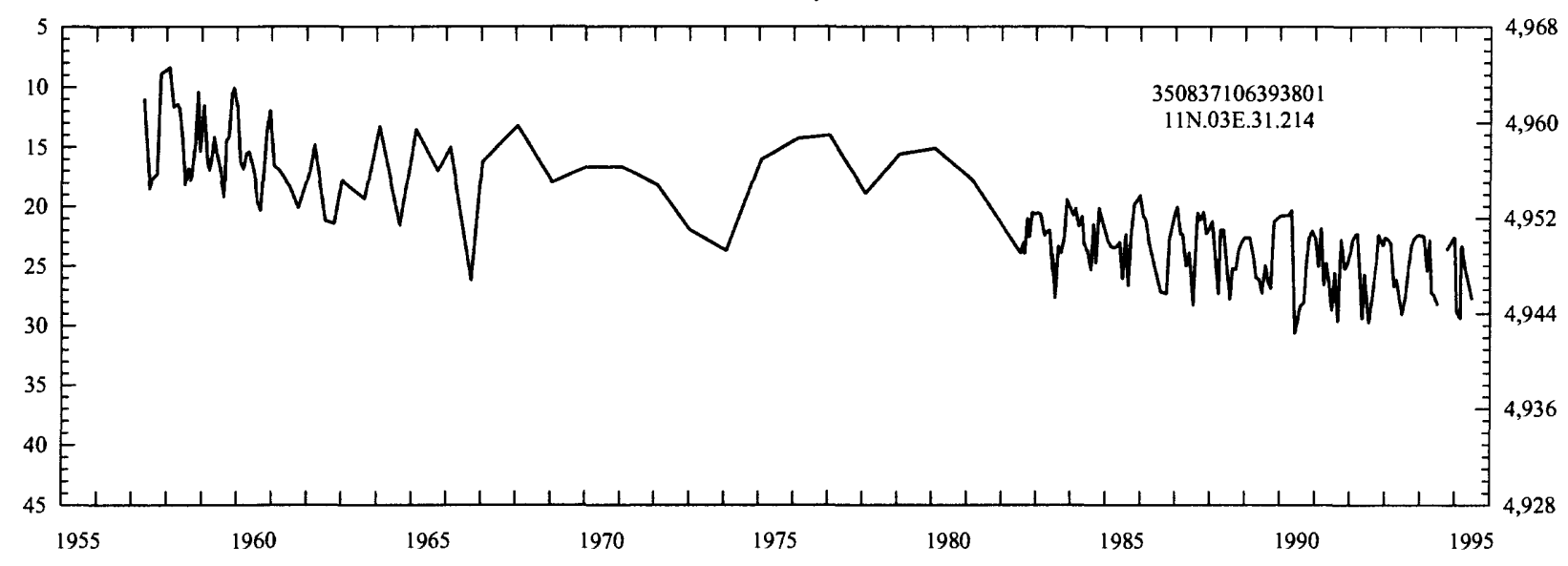

Site 66-City 2

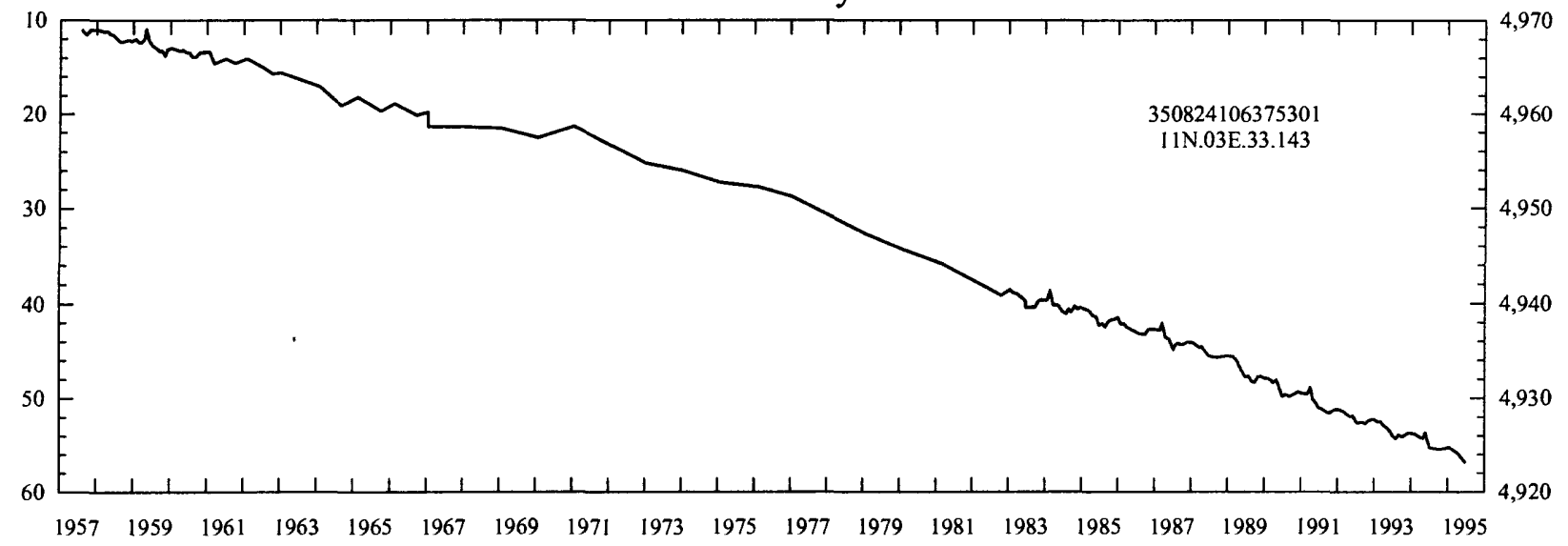

Figure 3.--Water-level data for selected wells and piezometers in the Albuquerque Basin--Continued. 

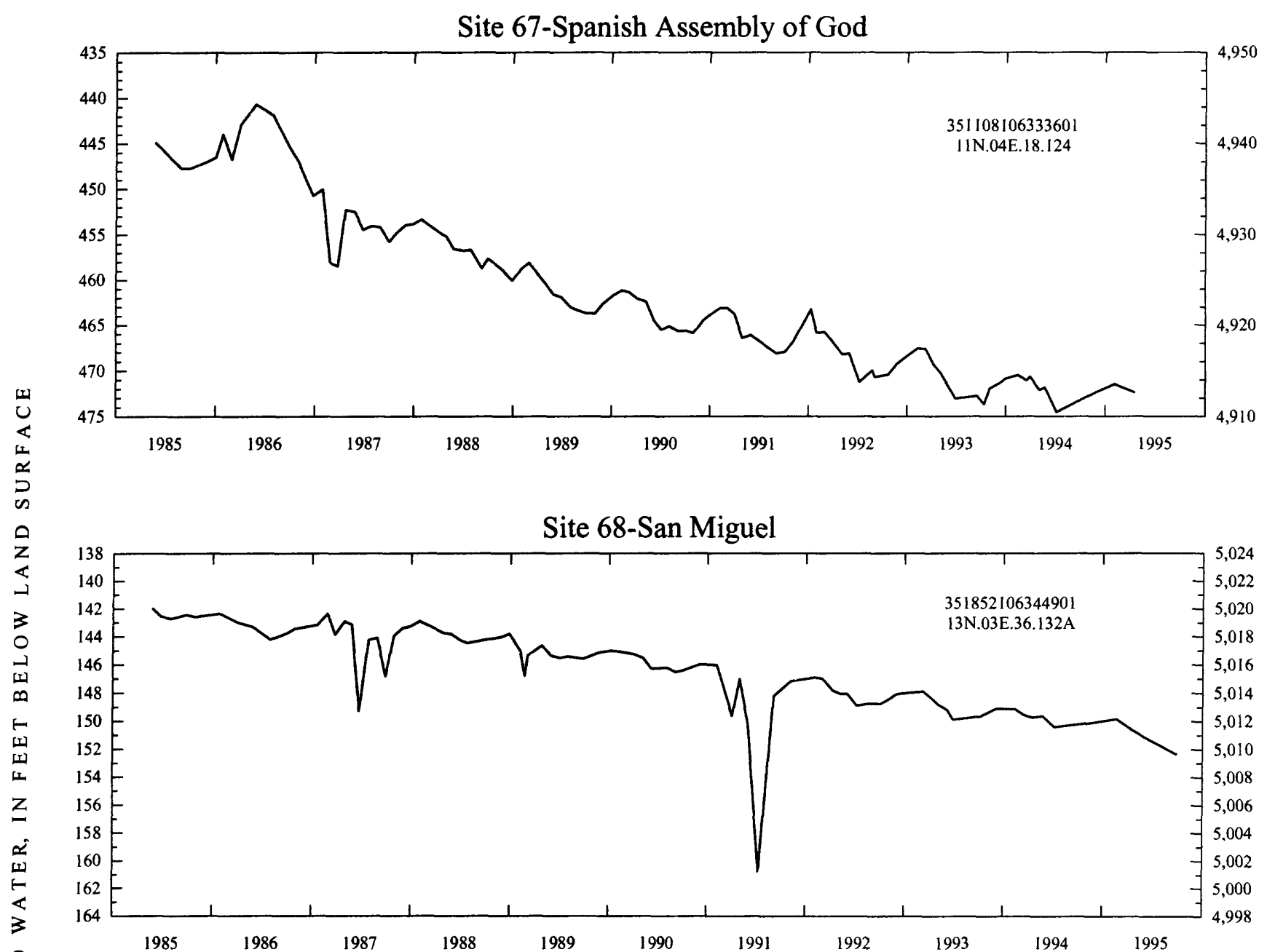

Site 69-Sandia Pueblo 2

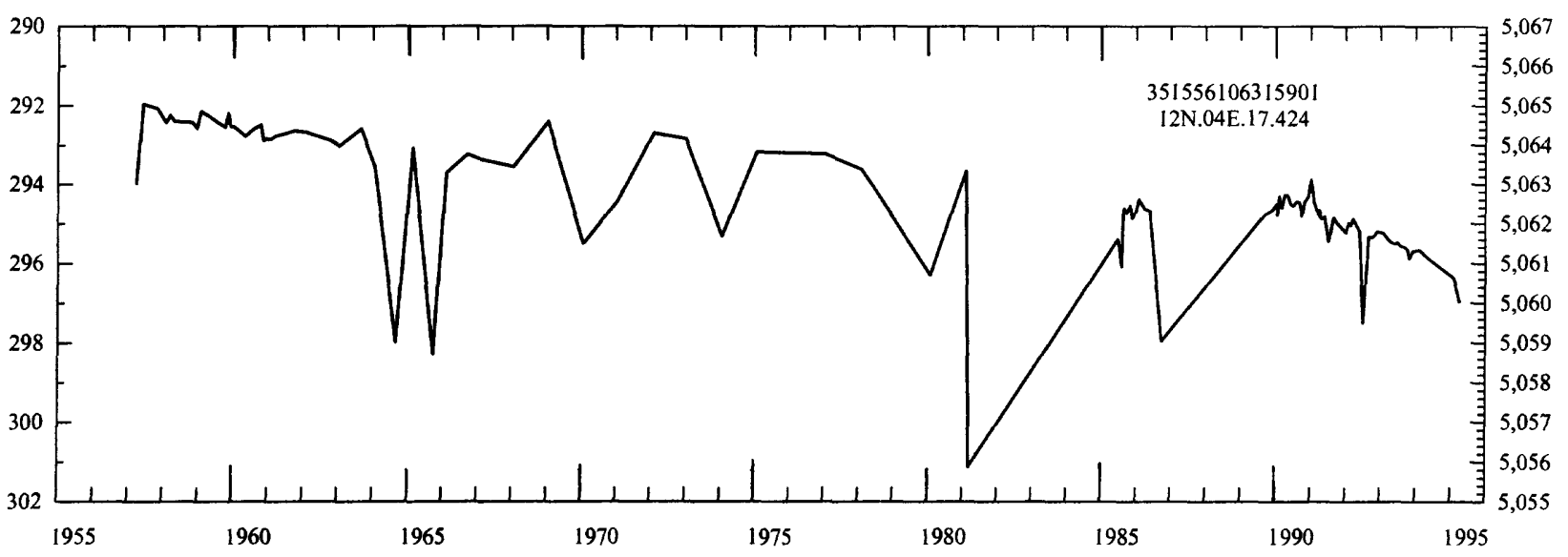

Figure 3.--Water-level data for selected wells and piezometers in the Albuquerque Basin--Continued. 
Site 70-Sandia Pueblo, North Bosque

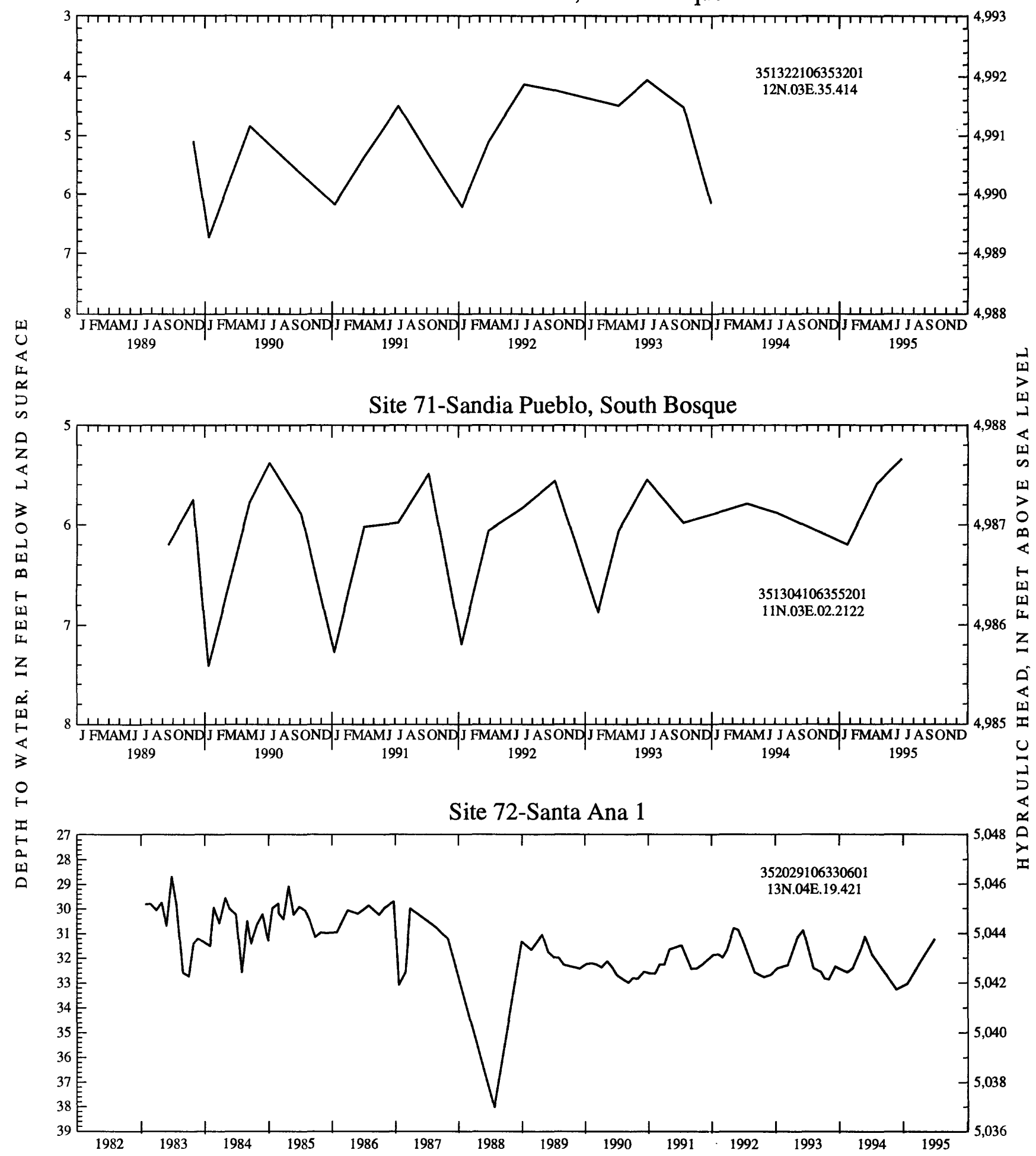

Figure 3.--Water-level data for selected wells and piezometers in the Albuquerque Basin--Continued. 
Site 73-Santa Ana 2

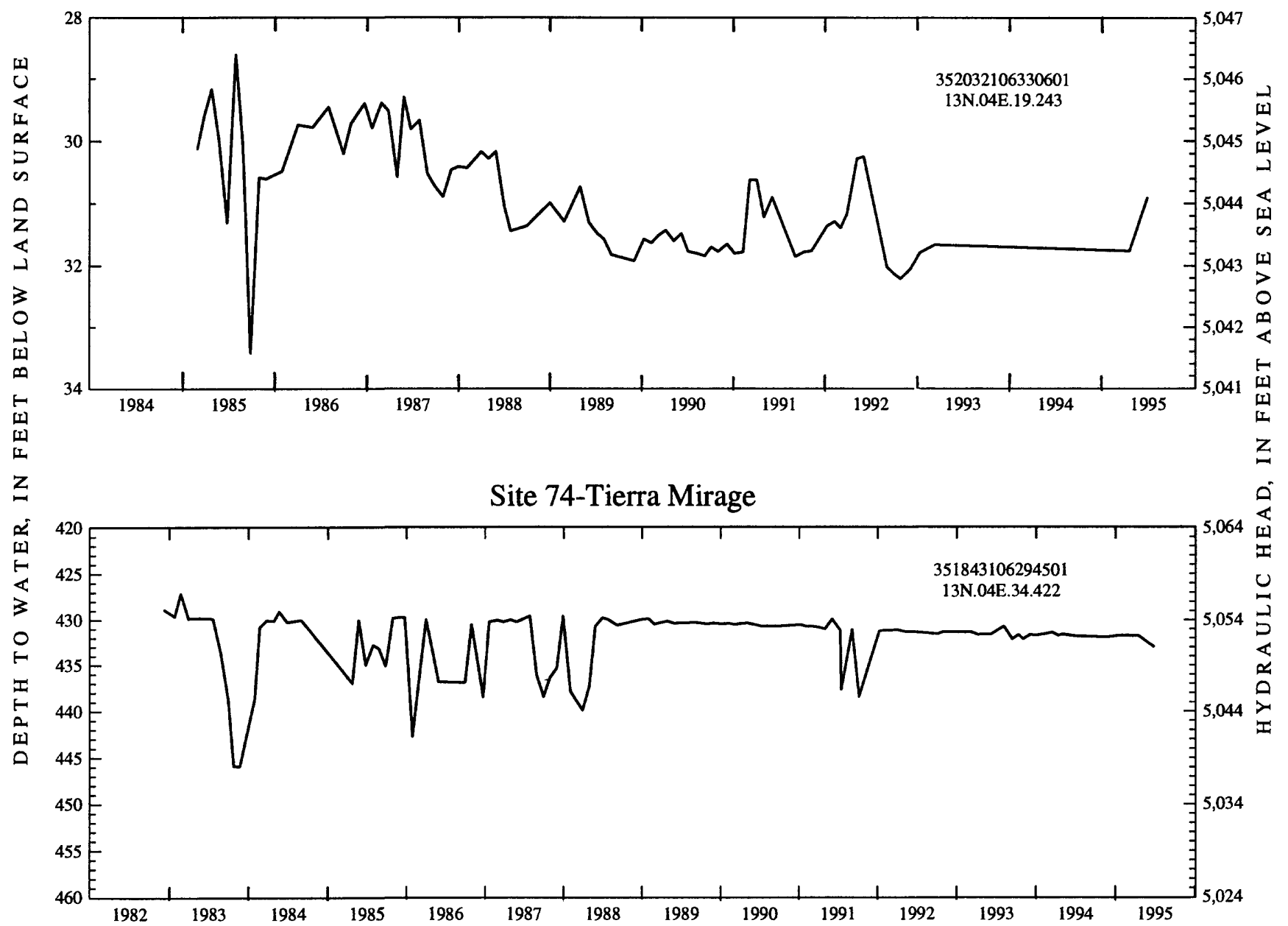

Figure 3.--Water-level data for selected wells and piezometers in the Albuquerque Basin--Concluded. 


\section{REFERENCES CITED}

Anderholm, S.K., and Bullard, T.F., 1987, Description of piezometer nests and water levels in the Rio Grande Valley near Albuquerque, Bernalillo County, New Mexico: U.S. Geological Survey Open-File Report 87-122, 51 p.

Kues, G.E., 1987, Ground-water-level data for the Albuquerque-Belen Basin, New Mexico, through water year 1985: U.S. Geological Survey Open-File Report 87-116, 51 p.

Thorn, C.R., McAda, D.P., and Kernodle, J.M., 1993, Geohydrologic framework and hydrologic conditions in the Albuquerque Basin, central New Mexico: U.S. Geological Survey WaterResources Investigations Report 93-4149, $106 \mathrm{p}$.

U.S. Bureau of the Census, 1980: Master area reference file for 1980 census. 1991: Master area reference file for 1991 census.

U.S. Department of Commerce, 1991, 1990 census of population and housing; Summary population and housing characteristics, New Mexico: 1990 CPH-1-33, variously paged.

Wilkins, D.W., 1986, Characteristics and properties of the basin-fill aquifer determined from three test wells west of Albuquerque, Bernalillo County, New Mexico: U.S. Geological Survey Water-Resources Investigations Report 86-4187, 78 p. 